\title{
Cardiovascular Diseases and Rheumatology
}

\author{
Rania Alhaj Ali, Hussein Halabi, \\ and Hani Almoallim
}

\subsection{Introduction}

The prevalence of various cardiovascular diseases (CVD) in the different rheumatologic disorders is a very important topic. Each disease has a number of unique manifestations despite the fact that an overlap is present due to shared common risk factors, which may be related to the longer life expectancy of the recent therapeutic advances. A growing understanding of the role of inflammation and immune system in the initiation and progression of atherosclerosis as well as the early detection of cardiovascular manifestations is due to the availability and use of sophisticated noninvasive cardiac and vascular diagnostic technology. Such discipline results in the detection of cardiac manifestation unique to each rheumatologic disorder. This was not possible previously due to short life expectancy, limited therapeutic interventions, vague understanding

\author{
R. A. Ali $(\bowtie)$ \\ King Faisal Specialist Hospital and Research Center, \\ Jeddah, Saudi Arabia \\ e-mail:n3527378@kfshrc.edu.sa \\ H. Halabi \\ Department of Internal Medicine, King Faisal \\ Specialist Hospital and Research Center, \\ Jeddah, Saudi Arabia \\ H. Almoallim \\ Medical College, Umm Al-Qura University (UQU), \\ Makkah, Saudi Arabia
}

of pathological process for each disease, and the limited diagnostic resources.

Cardiovascular diseases (CVD), including coronary artery diseases (CAD), can be present at the time of or after the diagnosis of rheumatologic disease. Cardiovascular association can be the principal introduction of the rheumatologic diseases in case of late diagnosis. The manifestations of CVD in rheumatologic diseases vary from subclinical to severe manifestations [4, 5], and they involve different structures of the heart. They can lead to significant morbidity and mortality. Therefore, we need to draw attention to their symptoms, to the risk factors that contribute to CVD development, as well as adaption of preventive measures that may control them. We will also consider the coronary artery disease (CAD), which maybe a crucial contributor to morbidity and mortality in numerous rheumatological diseases [6-9].

The prevalence of atherosclerotic CAD is increased in patients with chronic inflammatory rheumatic diseases, particularly in those with systemic lupus erythematous (SLE) and rheumatoid arthritis (RA) [10, 11]. The increased risk of CAD results from both traditional risk factors and factors unique to these rheumatic diseases [12, 13]. For example, accelerated atherosclerosis is one of the important risk factors for the development of $\mathrm{CAD}$, and it can be attributed to the prolonged inflammatory process in these diseases, vascular endothelial dysfunction, and a specific form of 
low-density lipoprotein (LDL). The importance of metabolic syndrome in various rheumatic diseases and its implications on morbidity and mortality will be discussed as metabolic syndrome, which is commonly diagnosed among those patients and also plays an important role in the CVD development [14-16].

Several medications are now used in the management of various rheumatologic diseases, which can affect the development of CADeither by decreasing or increasing the CAD severity or by decreasing or increasing its risk factors. In fact, many discussions are held nowadays with focus on how and when to use them. For example, the use of aspirin and statins in rheumatology and their effect on CAD. We will discuss the latest guidelines for their use here.

In this chapter, we address the various cardiovascular events that patients are exposed to, with $\mathrm{CAD}$ as one of the major factors that increase their mortality [10]. We will also discuss the important areas in regard to the identification of high-risk groups that need interventions, how to decrease the risk of CAD in these groups, and the way to better understand the effects of common medications on the risk of CAD in these patients.

\subsection{Cardiovascular Manifestations in the Rheumatic Diseases}

In this section, we look at CVD involvements in the different rheumatologic diseases and address the important issues in regard to their development (Tables 16.1 and 16.2 give a summary of the points given below).

The coronary artery disease (CAD) contributes significantly to the morbidity and mortality in various rheumatic diseases, whereas the occurrence of atherosclerotic $\mathrm{CAD}$ is increased in patients with chronic inflammatory rheumatic

Table 16.1 Type of CVD diseases

\begin{tabular}{|c|c|c|}
\hline Disease & CVD & \\
\hline \multirow[t]{2}{*}{ RA } & Atherosclerotic & $\begin{array}{l}\text { - Myocardial infarction. } \\
\text { - Congestive heart failure. } \\
\text { - Peripheral arterial disease. }\end{array}$ \\
\hline & Non-atherosclerotic & $\begin{array}{l}\text { - Pericarditis. } \\
\text { It is possible to occur as an inflammatory manifestation of RA. } \\
\text { - Myocarditis and endocarditis. } \\
\text { They are also possible to occur as a complication in RA. } \\
\text { - Vasculitis. } \\
\text { (e.g., aortitis, coronary arteritis) } \\
\text { It can cause neurovascular disease (e.g., mononeuritis multiplex), } \\
\text { cutaneous ulceration, or organ infarction based on the affected artery. } \\
\text { - Other less common complications. } \\
\text { Conduction abnormalities } \\
\text { - Amyloidosis. } \\
\text { - Pulmonary hypertension. }\end{array}$ \\
\hline \multirow[t]{3}{*}{ SLE } & Pericardium & $\begin{array}{l}\text { - Pericarditis. } \\
\text { - Pericardial effusion. }\end{array}$ \\
\hline & Myocardium & $\begin{array}{l}\text { - ECG findings: Prolonged PR intervals. } \\
\text { - MRI to help in diagnosis. }\end{array}$ \\
\hline & Endocardium and valves & $\begin{array}{l}\text { - Systolic murmur: Possibly from hyperdynamic state because of } \\
\text { anemia. } \\
\text { - Libman-sacks endocarditis . }\end{array}$ \\
\hline \multirow[t]{3}{*}{$\begin{array}{l}\text { Systemic } \\
\text { sclerosis }\end{array}$} & $\begin{array}{l}\text { Histology of CVD in } \\
\text { SSc }\end{array}$ & $\begin{array}{l}\text { - Hemosiderin deposits. } \\
\text { - Involvement of subendocardial layers. }\end{array}$ \\
\hline & Myocardium & $\begin{array}{l}\text { - Fibrosis affects the myocardium in both ventricles and the } \\
\text { conducting system. } \\
\text { - Tricuspid regurgitation. }\end{array}$ \\
\hline & Pulmonary arteries & $\begin{array}{l}\text { - Pulmonary hypertension with irreversible fibrosis at the arterial walls, } \\
\text { which will cause resistance against right ventricular contraction. }\end{array}$ \\
\hline
\end{tabular}


Table 16.1 (continued)

\begin{tabular}{|c|c|c|}
\hline Disease & \multicolumn{2}{|l|}{ CVD } \\
\hline \multirow{6}{*}{$\begin{array}{l}\text { Antiphos- } \\
\text {-pholipid } \\
\text { syndrome }\end{array}$} & CAD & $\begin{array}{l}\text { - MI and cardiac death with APL positive. } \\
\text { - Unstable angina. }\end{array}$ \\
\hline & Valvular disease & $\begin{array}{l}\text { - Mitral, aortic, and less common in tricuspid valves. } \\
\text { - It can progress to heart failure. }\end{array}$ \\
\hline & Pseudo-endocarditis & $\begin{array}{l}\text { - Vegetation commonly at the mitral and aortic valves. } \\
\text { - High APL. } \\
\text { - Blood culture is negative for infection. }\end{array}$ \\
\hline & Peripheral artery disease & - At lower extremities. \\
\hline & DVT & $\begin{array}{l}\text { - Most common venous manifestation. } \\
\text { - Pulmonary embolism is a common eventual complication. }\end{array}$ \\
\hline & Intracardiac thrombus & - Not common and usually misdiagnosed. \\
\hline \multirow[t]{4}{*}{$\begin{array}{l}\text { Ankylosing } \\
\text { spondylitis }\end{array}$} & Conduction defects & $\begin{array}{l}\text { Inflammation and fibrosis of interventricular septum will cause damage } \\
\text { of atrioventricular node, which can lead to first, second, and third-degree } \\
\text { heart block and bundle branch block }\end{array}$ \\
\hline & Aortic incompetence & $\begin{array}{l}\text { Aortic wall inflammation (aortitis) above and behind sinuses of valsalva, } \\
\text { and may extend below to the aortic roots and the wall of the mitral valve }\end{array}$ \\
\hline & $\begin{array}{l}\text { Left ventricular } \\
\text { dysfunction }\end{array}$ & A possible increased connective tissue involvement in the myocardium \\
\hline & Less common & $\begin{array}{l}\text { - Pericarditis. } \\
\text { - Cardiomyopathy. } \\
\text { - Mitral valve disease. } \\
\text { - Endocarditis. }\end{array}$ \\
\hline $\begin{array}{l}\text { Psoriatic } \\
\text { arthritis }\end{array}$ & \multicolumn{2}{|c|}{$\begin{array}{l}\text { - CAD } \\
\text { - Cerebral vascular disease. } \\
\text { - Peripheral vascular disease. }\end{array}$} \\
\hline $\begin{array}{l}\text { Inflammatory } \\
\text { myopathies }\end{array}$ & \multicolumn{2}{|c|}{$\begin{array}{l}\text { - Myocarditis. } \\
\text { - CAD. } \\
\text { - Affected myocardial small vessels. }\end{array}$} \\
\hline $\begin{array}{l}\text { Systemic } \\
\text { vasculitis }\end{array}$ & \multicolumn{2}{|c|}{$\begin{array}{l}\text { - CAD } \\
\text { - Myocardium, pericardium, endocardium, and conduction system involvements. } \\
\text { - Peripheral vascular disease. }\end{array}$} \\
\hline
\end{tabular}

Table 16.2 Summarized types of CVD in rheumatologic diseases

\begin{tabular}{l|l|l|l|l|l|l}
\hline Disease & RA & SLE & APS & SSc & AS & PSA \\
\hline MI & $\checkmark$ & $\checkmark$ & $\checkmark$ & $\checkmark$ & $\checkmark$ & $\checkmark$ \\
\hline CHF & $\checkmark$ & $\checkmark$ & & $\checkmark$ & $\checkmark$ & \\
\hline PAD & $\checkmark$ & $\checkmark$ & $\checkmark$ & & & $\checkmark$ \\
\hline PH & & & & $\checkmark$ & & \\
\hline Myocardial diseases & $\checkmark$ & $\checkmark$ & & $\checkmark$ & $\checkmark$ & $\checkmark$ \\
\hline Endocardial diseases & $\checkmark$ & $\checkmark$ & $\checkmark$ & & $\checkmark$ & \\
\hline Valvular disease & \pm & $\checkmark$ & $\checkmark$ & & $\checkmark$ & \\
\hline Pericarditis & $\checkmark$ & $\checkmark$ & & $\checkmark$ & $\checkmark$ & \\
\hline $\begin{array}{l}\text { Arteritis (coronary, } \\
\text { aorta) }\end{array}$ & & & & & & \\
\hline Conduction defects & \pm & & & $\checkmark$ & $\checkmark$ & $\checkmark$ \\
\hline
\end{tabular}

Symbol definitions, MI: Myocardial infarction, CHF: Congestive heart failure, PAD: Peripheral arterial disease, PH: Pulmonary hypertension, SSc: Systemic sclerosis, AS: Ankylosing spondylitis, PsA: Psoriatic arthritis. \pm : in case of rheumatoid nodule diseases, particularly those with SLE and RA. This again is emphasizing the importance of those conditions to the development of CAD. This increased risk is mediated by the presence of both traditional risk factors and factors unique to those with systemic inflammatory disorders. It is a matter of higher risk as well as the presentation.

A larger proportion of patients with RA has a clinical silent CAD in comparison to demographically similar individuals in the general population. Patients with RA are also less likely to report chest pain during an acute coronary event than those without RA. It is still uncertain why this is happening, but acceptable explanations include the following: many patients with active disease and joint damage are less physically active; therefore, they are less likely to place suf- 
ficient demand on the heart to elicit angina, which may attribute to RA pain. Patients with CAD tend to use nonsteroidal anti-inflammatory drugs (NSAID), glucocorticoids, or disease-modifying antirheumatic drugs (DMARDs), which can change their pain perception. Patients with rheumatoid arthritis (RA) have a reduced life expectancy when compared with the general population. Cardiovascular death is considered the leading cause of mortality in patients with RA; it is responsible for approximately half the deaths observed in RA [8]. Epidemiologic studies have shown that this increased mortality is largely attributed to cardiovascular diseases, primarily CAD. Considerable evidence suggests that inflammation plays a role in the pathogenesis of atherosclerosis [10]. The prevalence of cardiovascular comorbidity is difficult to assess accurately since $\mathrm{CAD}$ has a tendency to remain silent in the rheumatoid patients, but deaths from CVD occur earlier than in the general population. It has also been suggested that the increased risk of CAD in RA precedes the onset of clinical rheumatoid disease [17].

The lowering of CAD morbidity and mortality by recognizing patients at risk, and revealing their nontraditional ${ }^{1}$ risk factors as well as their contribution in developing cardiovascular complications are important. Many rheumatic diseases have their share of these complications, e.g., RA, SLE, and vasculitis. The studies showed the importance of prevention strategies. Furthermore, many studies have been discussing various reasons of the increased in cardiac manifestations and the risk of mortality due to CAD. One could be the increase of traditional risk factors and its explanation. The second could be the special nontraditional risk factors, which are related to the pathophysiology of rheumatic diseases (See Tables 16.1 and 16.2).

Traditional risk factors include smoking, ${ }^{2}$ hypertension, diabetes mellitus (DM), hyperlipidemia, and obesity [12].

${ }^{1}$ Patients are exposed to both the traditional risk factors of $\mathrm{CAD}$ and the nontraditional risk factors related to their disease.

${ }^{2}$ Apart from the known effects of smoking on CAD, it
The nontraditional risk factors are associated with elevation of CAD occurrences, which include severity of the disease, more extraarticular manifestation at presentation, corticosteroids, NSAIDs, and the low socioeconomic status. The presence of the accelerated atherosclerosis in those patients is associated with CAD development and subsequently the increased mortality from CAD in them (Tables 16.3 and 16.4).

\subsubsection{Rheumatoid Arthritis (RA)}

Rheumatoid arthritis is a chronic systemic inflammatory disease, which affects approximately $1 \%$ of the adult general population [18]. It has many extra-articular manifestations (e.g., heart and lung) in about $40 \%$ of patients with RA over their life time [19]. The mortality gap in comparison to the general population widened with the dramatic improvement in the overall mortality rate in the latter group [20]. For example, if we compare the general population to the patients with RA, there is an increased incidence of cardiovascular events, including myocardial infarction, stroke, and cardiac death among the patients with RA.

Cardiovascular disease is recognized as the leading cause of death in RA patients, accounting for nearly $40 \%$ of mortality [18]. Patients with RA are at twofold increased risk for myocardial infarction and stroke, with risk increasing to nearly threefold in patients who have had the disease for 10 years or more [18]. Congestive heart failure appears to be a greater contributor to excess mortality than ischemia. This increased cardiovascular disease risk in RA patients seems to be independent of traditional cardiovascular risk factors. Pathogenic mechanisms include prooxidative dyslipidemia, insulin resistance, prothrombotic state, hyperhomocysteinemia, and immune mechanisms, such as T-cell activation

increases the severity of the rheumatoid arthritis, which can lead to atypical manifestation of the CAD and increasing the difficulty of the early detection (Tables 16.3 and 16.4). 
Table 16.3 Prevalence of traditional risk factors

\begin{tabular}{l|l|l|l|l|l}
\hline Prevalence & Smoking & Hypertension & DM & Dyslipidemia & Obesity \\
\hline RA & $\uparrow \uparrow$ & $\uparrow$ & $\uparrow \uparrow$ & $\uparrow \uparrow$ & $\uparrow$ \\
\hline SLE & $\uparrow$ & $\uparrow \uparrow$ & $\uparrow$ & $\uparrow$ & $\uparrow$ \\
\hline General population & $\uparrow$ & $\uparrow$ & $\uparrow$ & - & $\uparrow$ \\
\hline
\end{tabular}

Table 16.4 Effects of traditional risk factors on RA

\begin{tabular}{|c|c|}
\hline Effects of & RA \\
\hline Smoking & $\begin{array}{l}\uparrow \mathrm{RA} \text { development } \\
\uparrow \mathrm{RF} \text { and ACPA-positive RA } \\
\uparrow \text { worse prognosis }\end{array}$ \\
\hline Hypertension & $\begin{array}{l}\uparrow \text { more than the general population, } \\
\text { it is unclear whether it is from } \\
\text { under diagnosis or from under } \\
\text { treatment } \\
\uparrow \mathrm{BP} \text { from NSAIDs, chronic } \\
\text { corticosteroids, leflunomide, and } \\
\text { cyclosporine }\end{array}$ \\
\hline $\mathrm{DM}$ & $\begin{array}{l}\text { Possible association between RA } \\
\text { and insulin resistance } \\
\text { Can predict a new cardiovascular } \\
\text { event }\end{array}$ \\
\hline Dyslipidemia & $\begin{array}{l}\downarrow \text { or } \uparrow \text { Total lipid } \\
\downarrow \text { or } \uparrow \text { LDL } \\
\downarrow \downarrow \text { HDL } \\
\text { Can predate the diagnosis of RA }\end{array}$ \\
\hline BMI & $\begin{array}{l}\uparrow \mathrm{BMI} \text { and obesity }=\uparrow \text { other } \\
\text { traditional risk factors }=\uparrow \text { worse } \\
\text { prognosis }=\text { CVD } \\
\downarrow \text { BMI and cachexia }=\text { acute } \\
\text { inflammation }\end{array}$ \\
\hline
\end{tabular}

that subsequently lead to endothelial dysfunction, a decrease in endothelial progenitor cells, and arterial stiffness, which are the constitutes of accelerated atherosclerosis observed in RA patients [18]. These patients are greatly susceptible to CAD (myocardial infarction and angina), heart failure, pericarditis, myocarditis, atrial fibrillation, valvular heart disease, and cardiac amyloidosis.

\subsubsection{Pericarditis}

Pericarditis is the most common cardiac manifestation in RA, which is usually an asymptomatic disease. Clinical pericarditis is observed in around $4 \%$ of the patients [21], which is lower than the autopsy proven one that occurs in around $30 \%-50 \%$ of patients with RA [22]. Patients with
RA are more likely to develop pericardial effusion than the ones without RA by ten times [23]. Most of the patients develop the pericardial effusion after the onset of the arthritis; however, RA was diagnosed after pericardial effusion in a minority of patients [3]. The variables associated with the development of extra-articular manifestations including pericarditis are as follows: male gender, presence of increased serum concentrations of rheumatoid factor, joint erosions, subcutaneous nodules, number of disease-modifying antirheumatic drugs (DMARD), presence of nail fold lesions, and any other extra-articular feature 1 year before the time of the diagnosis, or treatment with corticosteroids at the time of the diagnosis [21].

Patients with findings of edema, shortness of breath, chest pain, raised jugular venous pressure, pericardial rub, and paradoxical pulse were found to have $100 \%$ mortality rate within 2 years [4]. In patients with pericardial effusion, the diagnosis of RA was mainly clinical without the need for invasive procedure [3]. Biologic agents are now considered one of the cornerstones of RA therapy associated with the development of pericardial effusion mostly within 4 months of the start of the infliximab and etanercept [24]. Purulent pericardial effusion was reported in patients receiving infliximab and etanercept $[25,26]$.

Treatment: Although most of the evidence came from patients with immune-mediated pericarditis, it can be extrapolated to the RA-associated pericarditis as follows:

1. Asymptomatic disease usually diagnosed accidently will resolve spontaneously.

2. Symptomatic disease therapy includes the following:

- Nonsteroidal anti-inflammatory drug (NSAID) is the mainstay therapy for idio- 
pathic pericarditis, and the two agents that proved their efficacy are ibuprofen and indomethacin [27].

- Corticosteroids: low- to moderate-dosage prednisone $(0.2-0.5 \mathrm{mg} / \mathrm{kg}$ per day) for 4 weeks and then slowly tapered, if the patient is intolerant to aspirin or NDSAID or with pericardial effusion [27].

- Colchicine: in patients with acute and recurrent pericarditis in addition to aspirin or NSAID in the dose of $0.5 \mathrm{mg}$ twice daily in patients $>70 \mathrm{~kg}$ and $0.5 \mathrm{mg}$ once daily in patients $\leq 70 \mathrm{~kg}$ [27].

- If previous medical treatment fails, there is growing evidence for oral azathioprine, intravenous human immunoglobulins, and anakinra [27].

- Tocilizumab was reported to be successful too [28, 29].

- Surgical management includes pericardiocentesis, pericardiectomy, or pericardiotomy in the cases of hemodynamic compromise, cardiac tamponade, or constrictive pericarditis.

- Biologic-agents-associated pericarditis should be stopped and treated accordingly [24].

- Purulent pericarditis with biologic agents should be stopped and antibiotic therapy to be used accordingly $[25,26]$.

\subsubsection{Myocardial Involvement}

Myocarditis is less common than RA-associated pericarditis. It was found in $19 \%$ of patients with RA based on post-mortem study where the majority were females with active arthritis; however, most of the patients with myocarditis were clinically asymptomatic [30].

Cardiomyopathy with finding of left ventricle hypertrophy (LVH) was found in around $37 \%$ of asymptomatic RA patients by echocardiography [31]. The pathohistological finding was either diffuse or focal inflammation of the myocardium [32].

Diagnosis: The left ventricle function is usually evaluated with echocardiography, but it has a limited role in the evaluation of myocardium involvement. Cardiac magnetic resonance imag- ing (CMR) is helpful as noninvasive evaluation tool for myocarditis as it shows increased T2-weighted edema ratio (ER) score suggesting myocardial tissue edema. It has a role too in identifying the chronicity of myocarditis [33].

Treatment: Conventional therapy to support the left ventricle function is generally used. Highdose prednisolone $(60 \mathrm{mg})$ daily for 2 months, tapered over 4 months followed by maintenance dose, normalizes the left ventricle ejection fraction and the gallium uptake [34].

\section{Antimalarials-Induced Cardiotoxicity}

Hydroxychloroquine and chloroquine are medications initially used as antimalarial treatment. They found to be effective as disease-modifying antirheumatic drugs. Hydroxychloroquineinduced cardiotoxicity has been reported in patients with RA [35].

Risk factors: Old age, female sex, long duration of therapy, high daily dose, preexisting cardiac disease, or renal impairment [35].

Presentation: Features of systolic dysfunction and prolonged QT interval were reported too [35].

Diagnosis:

(a) Echocardiography shows diffuse thickening ventricular walls [35].

(b) CMR: Shows areas of patchy gadolinium enhancement. It is important to differentiate it from other causes of cardiomyopathy [35].

(c) Endomyocardial biopsy: Shows enlarged and vacuolated cells, and the presence of myeloid and curvilinear bodies within the cardiac myocytes [35].

Treatment: Mainly withdrawal of the antimalarial agents and conventional heart failure treatment if needed [35].

\subsubsection{Heart Failure}

It is a clinical syndrome that is two times higher in RA patients than the general population [36].

Associations: Rheumatoid factor positivity was associated with higher risk of congestive heart failure [36].

Causes: Patients with RA develop heart failure mostly due to ischemic cardiomyopathy, 
drug-induced myopathy (e.g., antimalarial drugs), rheumatoid nodule, NSAID use, or amyloidosis.

Treatment: Treat the underlying cause and conventional heart failure treatment. Avoid the use of tumor necrosis factor-alpha (TNF alpha) inhibitors especially the high doses $(10 \mathrm{mg} / \mathrm{kg})$ in NYHA classes 3 and 4 heart failure [37]. In patients with congestive heart failure and RA, the combined use of synthetic DMARDs, non-TNF biologic, or tofacitinib over TNF inhibitors is recommended [38].

\subsubsection{Coronary Artery Disease (CAD)}

Patients with rheumatoid arthritis (RA) have a reduced life expectancy when compared with the general population, where cardiovascular death is considered the leading cause of mortality in patients with RA; it is responsible for approximately half the deaths observed in RA [8]. Epidemiologic studies have shown that this increased mortality is largely attributable to cardiovascular diseases, primarily CAD. Considerable evidence suggests that inflammation plays a role in the pathogenesis of atherosclerosis [10]. The prevalence of cardiovascular comorbidity is difficult to assess accurately because CAD has a tendency to remain silent in the rheumatoid patient, but deaths from CVD occur earlier than in the general population. It has also been suggested that the increased risk of CAD in RA precedes the onset of clinical rheumatoid disease [17].

Traditional risk factors for atherosclerosis, such as smoking, hypercholesterolemia, hypertension, DM, and sedentary lifestyle, may be more common in RA than in the population as a whole but do not account for all of the increase in the disease. Currently, there is a large body of evidence that a chronic inflammatory state can enhance the harmful effects of some traditional risk factors, such as the association between systemic inflammation and arterial wall stiffness in hypertension or the proatherogenic lipid profile (high LDL and lipoprotein (a) low HDL) seen with increasing rheumatoid disease activity. The burden of addressing CAD in RA is therefore divided between rigorous control of traditional risk factors and effective disease control through immunosuppression [39]. The more extended the span of the RA and the utilization of TNF alpha inhibitors are, there is a chance for improvement of atherosclerosis [40]. The two are a surrogate for the seriousness of the illness and a presence of coronary calcification [41]. Male gender and severe inflammatory state (high inflammatory markers and disease activity score) are usually associated with atherosclerosis [42].

Factors influencing cardiovascular disease in rheumatoid arthritis:

- Oxidized LDL (oxLDL) and antibodies to oxidized LDL are both established as significant risk factors for CVD in RA. It has been consistently observed that the levels of oxLDL are higher in patients with active disease [39].

- C-reactive protein: Higher levels of CRP are associated with CVD in non-RA patients [39]. Treatment of CAD with statins or angiotensinconverting enzyme (ACE) inhibitors has been demonstrated to lower CRP levels [39]. Attention was specifically focused on highsensitivity CRP (hsCRP). Raised hsCRP is found in hypertension, smoking, and DM, as well as CAD.

In RA baseline, CRP predicts cardiovascular mortality [43], and the molecule acts directly in a pro-inflammatory manner at a range of sites. For example, CRP activates vascular endothelial cells to express adhesion molecules in a dose-dependent manner, and CRP activates monocyte chemotactic protein-1 (MCP-1), which can be inhibited by statins and fenofibrates [39].

- Homocysteine: Homocysteine is increasingly regarded as an epiphenomenon of CAD rather than a causative factor [39].

Elevated levels of homocysteine have been associated with CAD in the general population as well as in reduced levels of various vitamins including folate and B6 [39]. It has also been shown that homocysteine is present in higher concentrations in the joints of RA patients, where it may enhance production of pro-inflammatory cytokines such as IL-1 and thus act as a driver for 
joint damage; it may also accelerate atherosclerosis in a similar manner [44].

- Physical disability due to rheumatoid arthritis: Poor functional status, especially in the lower limbs, is a powerful predictor of mortality in RA, while regular exercise is known to have beneficial effects on the cardiovascular system. Exercise capacity is also inversely related to the presence of metabolic syndrome [45]. Patients with chronic RA have physical disabilities, which prevent them from taking regular exercise. This influences CAD in several ways; the presence of CAD usually causes delay in the individual's presentation to clinician since reduced physical activity may not exacerbate symptoms. The delay in presentation would also prevent treatment at an earlier stage of CAD, even with the lack of CVD, physical disability would still stop adequate exercise.

- Leptin and the adipocytokines: Leptin is an adipokine that functions both as a hormone and a cytokine. It is produced by the adipose tissue, and its main role appears to be to reduce food intake and to stimulate the sympathetic nervous system. It is known to stimulate inflammatory cytokine production, and to have direct deleterious effects on articular cartilage. It is also known to cause endothelial dysfunction, oxidative stress, and platelet aggregation and to be elevated in RA; while fasting has been implicated as a means of reducing leptin levels and improving RA disease activity [39]. Leptin has the potential to play a key role linking obesity, inflammation, and cardiovascular damage.

\section{Prevention of CAD in RA.}

Since it is generally similar to prevention in patients without RA [46], here are some important points to prevent CAD in RA patients.

One needs to:

- Stop smoking.

- Measure fasting blood glucose annually or in the event of significant weight gain especially in patients taking steroids. In already diabetic patients, the steroids should be kept in the lowest dose.

- Monitor blood pressure for RA patients before beginning medications and then at regular intervals for patients using NSAID, cyclosporine, and corticosteroids. NSAIDs reduce the antihypertensive effects of diuretics, $\beta$-blockers, and angiotensin-converting enzyme inhibitors, but it is less likely to interfere with calcium channel blockers [47]. In those group of patients either to increase the dose of the antihypertensive medications or to use a calcium channel blocker.

- Manage hypercholesterolaemia according to recommendation for the general population.

- Manage obesity as well as weight loss.

- Supplement the diet with fish oil that is rich in omega-3 fats, because this has demonstrated efficacy in the treatment of RA, facilitated reduction of NSAIDs use and reduced cardiovascular mortality risk [48].

- Diagnose and treat RA early:

- Methotrexate: shown to decrease cardiovascular mortality among RA patients [49].

- TNF inhibitors: shown to decrease the risk of MI among patients who have controlled synovitis within 6 months of treatment [50].

\subsubsection{Rheumatoid Nodule}

Valvular nodule is 10 times higher in RA patients than the general population [23].

Incidence: Echocardiographic evidence of aortic valve nodule was observed less than mitral valve nodule in the rate $0.3 \%$ vs. $0.6 \%$ among RA patients [31], respectively.

Presentation: Differs according to the site of the nodule, as it causes functional impairment, such as arrhythmias and valve disease [51]. It was associated with complete atrioventricular (AV) block necessitating pacemaker as it involves the AV node [52, 53].

Treatment: According to the presentation.

\subsubsection{SLE}

It is a multisystem autoimmune disease with a strong female predilection. 
Cardiovascular morbidity and mortality is a frequent complication, particularly in females aged 35-44 years, where the risk of myocardial infarction is raised 50-fold [54]. The cardiac morbidity is the most common cause of death in SLE patients, which is around 25\% of deaths in SLE [55].

The heart is one of the most frequently affected organs in systemic lupus erythematosus (SLE), where any part can be affected, including the pericardium, myocardium, coronary arteries, valves, and the conduction system. In addition to pericarditis and myocarditis, high incidence of CAD has become increasingly recognized as cause of mortality, especially in older adult patients and those with long-standing SLE [56].

Pericarditis is the most common cardiac abnormality in SLE patients, but lesions of the valves, as well as myocardium and coronary vessels, may all occur. In the past, cardiac manifestations were severe and life threatening, often leading to death. Therefore, they were frequently found in postmortem examinations. Nowadays, cardiac manifestations are often mild and asymptomatic. However, they can be frequently recognized by echocardiography and other noninvasive tests (Echocardiography is a sensitive and specific technique in detecting cardiac abnormalities, particularly mild pericarditis, valvular lesions, and myocardial dysfunction). Therefore, echocardiography should be performed periodically on SLE patients [57].

\subsubsection{Pericarditis}

The most common clinical cardiovascular manifestation of SLE.

Prevalence: Echocardiographic evidence of pericardial effusion was detected in $27 \%$ of SLE patients, where most of them had asymptomatic disease [58]. Lupus pericarditis occurs predominantly in females in around 92\% [59] which is mostly due to main predominance of SLE in females.

Associations: Mostly associated with active SLE in $93 \%$ and involvement of other organs with SLE in $72 \%$ [59]. In the absence of renal failure, constrictive pericarditis or pericardial effusion is rarely reported [60]. Patients with tamponade had lower serum level of $\mathrm{C} 4$ in com- parison to the ones who did not develop tamponade [61].

Clinical presentation: Ranges from asymptomatic to pericardial effusion [58] to cardiac tamponade in $16 \%$ [59].

Diagnosis: Either by the presence of pericardial effusion by echocardiography only or the presence of 2 out of 4 of the following (Retrosternal pain, pericardial friction rub, widespread ST-segment elevation, and new/ worsening pericardial effusion) among SLE patients [59].

Treatment: The treatment of lupus pericarditis is mainly derived from immune-mediated pericarditis, as previously mentioned in the RA section, where it responded well to NSAID and corticosteroids [59]. High-dose corticosteroids, complete drainage, and pericardial window were used for treating patients with large pericardial effusion/tamponade [61, 62].

\subsubsection{Myocarditis}

Effects: SLE is associated with the increase in the left ventricle mass, and this would be even more if SLE was associated with hypertension (HTN) [63].

Associations: The association is strong between lupus myocarditis with the presence of myositis but weak with the presence of the antibodies to nuclear ribonucleoprotein (RNP) [64]. High SLE Disease Activity Index is an independent risk factor in the development of lupus myocarditis [5], where anticardiolipin IgG and lupus anticoagulant were positive in patients with severe symptoms [65].

Clinical features: It ranges from asymptomatic disease discovered accidently to symptomatic heart failure and sudden death [5].

Diagnosis: Echocardiography: Most patients suffered from wall motion abnormalities (WMA), whereas less than $50 \%$ of lupus myocarditis patients showed decrease in the left ventricle ejection fraction after the exclusion of other causes of myocarditis [5].

Treatment: Conventional treatment of heart failure [5]. Immunosuppressive therapy (highdose systemic corticosteroids with subsequent dose tapering, intravenous immunoglobulin, plasmapheresis, or cyclophosphamide) showed 
improvement in heart failure symptoms, EF, and the WMA of the heart [5]. After corticosteroids therapy, the EF improved up to a mean of $49.5 \%$ after around 7 months of follow-up from a mean of $33.8 \%$ [66]; one article reported normal EF after follow-up [67]. Refractory lupus myocarditis can be treated with rituximab [68]. Intravenous "pulse" cyclophosphamide was used in patient with lupus myocarditis refractory to corticosteroids, and it showed improvement in heart failure symptoms and EF from $19 \%$ to $63 \%$ [69]. Mycophenolate mofetil was effective in a case series [70]. Intravenous immunoglobulin was effective in the treatment of patients with severe lupus myocarditis in conjunction with corticosteroids and cyclophosphamide [65]. One rare case report showed that plasmapheresis and extracorporeal membrane oxygenation (ECMO) were effective in lupus myocarditis [71].

\subsubsection{Coronary Artery Disease (CAD)}

Prevalence: The prevalence of the angina, myocardial infarction, and sudden cardiac death was found to be $8.3 \%$ as per a Johns Hopkins SLE cohort study [9]. Another study found more than 50-fold risks of MI in young women 35-44 years old when compared to the control group [11].

\section{Risk Factors}

(a) Traditional risk factors for atherosclerosis. It has an increased prevalence in patients with SLE as hypertension, DM, premature menopause, sedentary lifestyle, and high homocysteine level [12].

(b) Inflammation-related risk factors.

- High disease activity and elevated level of CRP [13].

- In lupus nephritis, it was found that patients with long-term lupus nephritis had frequent episodes of cardiac lesions, mainly cardiac infarctions [72].

- Low serum levels of C3, antiphospholipid antibodies (APL), and elevated levels of antibodies to anti-ds DNA were found to be independent predictors of thrombosis. Hydroxychloroquine is pro- tective against future thrombosis in those patients [73].

- Several autoantibodies such as anti-DNA, APL, anti-SSA (Ro antibodies), and antiendothelial cell antibodies present in patients with SLE can mediate cardiac damage [74].

- Old age at diagnosis of SLE $[9,11]$.

- Longer duration of SLE $[9,11]$.

- Longer duration of steroid therapy [9].

- High levels of oxidized low-density lipoprotein cholesterol and homocysteine [9].

\section{Preventions of CAD in SLE.}

To prevent $\mathrm{CAD}$, one has to:

- Control the traditional risk factors, to use the statins according to the guidelines for the general population, and to control blood pressure aggressively.

- Improve the lipid profile by using hydroxychloroquine as it lowers the level of the cholesterol in the blood, especially in patients taking steroids [75], and it is associated with a reduced risk of DM [76].

- Minimize the use of steroids.

\subsubsection{Endocarditis (Libman-Sacks Endocarditis)}

It was first described by Libman and Sacks in 1942 after they discovered valvular lesions in four patients with SLE.

Prevalence: Echocardiographic evidence was detected in around $11 \%$ of patients with SLE [77].

Associations: It was found to be associated with longer SLE duration and activity, thrombosis, stroke, thrombocytopenia, and antiphospholipid syndrome [77]. Its coexistence with antiphospholipid antibodies (APLs) increases the risk of thromboembolic complications, especially stroke [78].

Pathology: Since the main involved valve is the mitral followed by the aortic [78], the left side is mainly more involved than the right. Therefore, the main dysfunction is regurgitation; stenosis is rarely found [78].

Diagnosis: Echocardiography: It is manifested as valve vegetations, thickening, and/or 
regurgitation [79]. Transesophageal echocardiography (TEE) was found to be more sensitive than transthoracic echocardiography (TTE) for the detection of echocardiographic findings [79]; for example, valvular thickening was found higher with TEE at $70 \%$ vs. $52 \%$ with TTE [79].

How to differentiate it from infective endocarditis? Infective endocarditis is an uncommon complication of SLE, yet at the same time, it should be in the differential diagnosis as both diseases can be presented with fever and valvular vegetation. Three laboratory tests can help differentiate between them to a degree, and these are the white blood cell count (WBC), the CRP level, and the antiphospholipid antibody (APL) level [80]. The test results show that the WBC is expected to be low during lupus flare and high during infection, CRP is high with infection and suppressed during lupus flare, and the aPL is high in SLE and unlikely to be positive in infection [80].

\section{Treatment}

The control of the SLE disease activity is important with the use of the corticosteroids. Although the use of corticosteroid is not beneficial for the valve lesion, it is important to control underlying diseases [78]. The corticosteroids, on the other hand, were noted to be associated with fibrosis and severe dysfunction (e.g., mitral valve insufficiency) after high doses of corticosteroid are used [81, 82]. Patients with Libman-Sacks Endocarditis, who suffered from a thromboembolic event, are recommended to be on life-long anticoagulation to prevent further episodes [78]. Accordingly, conventional treatment of heart failure and valvular lesion as needed is crucial.

\subsubsection{Systemic Sclerosis (SSc)}

Widespread vascular lesions, fibrosis of the skin, and internal organs characterize a connective tissue disease. More than half of the patients with SSc, who underwent autopsy, were found to have significant cardiac abnormalities [37]. Cardiac involvement is recognized as a poor prognostic factor when clinically evident, with a 5-year mortality rate is around 75\% [83]. Primary myocardial involvement is common in SSc; increasingly, evidence strongly suggests that myocardial involvement is related to repeated focal ischemia leading to myocardial fibrosis with irreversible lesions. Reproducible data have shown that this relates to microcirculation impairment with abnormal vasoreactivity, with or without associated structural vascular abnormalities. Consistently, atherosclerosis and macrovascular coronary lesions do not seem to be increased in SSc. Myocardial involvement leads to abnormal systolic, diastolic left ventricular dysfunction, and right ventricular dysfunction. Sensitive and quantitative methods have demonstrated the ability of vasodilators-including calcium channel blockers and angiotensin-converting enzyme inhibitors- to improve both perfusion and function abnormalities. By that, they emphasize the critical role of microcirculation impairment [84].

Asymmetric hypertrophy of the interventricular septum with signs of sub-aortic obstruction consistent with hypertrophic obstructive cardiomyopathy was evident in echocardiogram in patients with diffuse SSc. Hypertrophic cardiomyopathy is associated with the human lymphocyte antigen HLA DR3 [85], and this may provide a possible link with SSc as this HLA phenotype is common in the latter condition [85].

\subsubsection{Myocardial Fibrosis}

Prevalence: Around $66 \%$ of patients with SSc based on MRI [86]. The presence of the left ventricle (LV) dysfunction (ejection fraction (EF) $<55 \%$ ) was reported in around $5.4 \%$ among SSC patients [1].

Pathology: Patchy distribution of myocardial fibrosis is pathognomonic [87]; Foci of contraction band necrosis (mostly due to the recurrent vasospasm of the small vessels of the heart) is found in all parts of the myocardium mainly in the subendocardial area [88]. Asymptomatic patients with impaired coronary flow reserve did not show stenotic lesions of the major epicardial coronary arteries [89]. Contrarily, symptomatic patients (e.g., angina) with SSc had evidence of CAD in similar rate to the symptomatic ones without SSc [90].

Associations: There is association between the high volume of fibrosis and Raynaud's phenomenon duration of 15 years or more and 
abnormal Holter study results [86]. Male sex, old age, presence of digital ulcerations, and myositis were associated with higher prevalence of LV dysfunction [1].

\section{Diagnosis}

(a) Echocardiography: Most patients had LV hypertrophy in around $22.6 \%$, followed by LV diastolic dysfunction in around $17.7 \%$, and a rare percent of LV systolic dysfunction in around $1.4 \%$, in the absence of the pulmonary arterial hypertension [91].

(b) Heart MRI: Delay enhancement MRI can identify areas of fibrosis in a significant number of patients [86].

\section{Treatment}

Vasodilators (e.g., calcium channel blockers and angiotensin-converting enzyme (ACE) inhibitors) showed improvement of the myocardial perfusion and halting of the disease progression [92]. Patients showed radiological improvement in myocardial perfusion and function after the administration of nifedipine (60 mg daily) for 14 days [93]. Among SSc patients, it was found that the ones treated with calcium channel blockers (CCB) have less reduced LVEF [1]; the cardiac protective effect of CCB still needs to be established.

\subsubsection{Myocardial Ischemia}

$\mathrm{SSc}$ is an independent risk factor for acute myocardial infarction with no protective effect was noted with the immunosuppressive therapy [6].

\subsubsection{Pericarditis}

Prevalence: Symptomatic pericardial disease is observed in around (5-16\%) of the patients, which is lower than the autopsy proven one and was demonstrated in around (33-72\%) of SSc patients [94]. Symptomatic pericarditis in patients with limited scleroderma is more than the patients with diffuse scleroderma, which was observed at the rate of $30 \%$ vs. $16 \%$, respectively [2].

Associations: Symptomatic pericarditis is associated with pulmonary hypertension [95], while cardiac tamponade and heart failure are associated with poor prognosis [87].

Presentation: It is usually asymptomatic [2], yet it can rarely be present with large symptomatic pericardial effusion [2]. The large pericardial effusion usually occurs after the clinical and laboratory manifestations of the scleroderma [2], but still it can happen before, so it is part of the differential diagnosis of pericardial effusion [96]. Renal failure can be presented in the setting of large pericardial effusion and constrictive pericarditis [87].

Laboratory: exudative pericardial effusion pattern with predominance of mononuclear cells [97].

Treatment: In the setting of pericarditis, NSAID and corticosteroids were effective [94], and with the presence of active inflammation, immunosuppressive therapy may have a role [94].

Conventional heart failure treatment is helpful [94]. Cardiac tamponade is to be treated accordingly, e.g., pericardiocentesis [87]. Constrictive pericarditis is to be treated accordingly, e.g., diuretics, sodium and fluid restriction, and/or pericardial stripping [87].

\subsubsection{Antiphospholipid Syndrome}

Antiphospholipid syndrome (APS) is a systemic autoimmune disease associated with arterial and venous thrombotic events and recurrent fetal loss. The heart is a target organ in APS.

Endocardial disease, intracardiac thrombosis, myocardial involvement including CAD and microvascular thrombosis, as well as pulmonary hypertension, have all been described in APS patients. Valvular involvement is the most common manifestation with a prevalence of $82 \%$ detected by transesophageal echocardiography. Symmetrical-nodular thickening of the mitral and/or aortic valves-is characteristic. Anticoagulant/antiplatelet treatment is ineffective in terms of valvular lesion regression [98]. Some patients require cardiac valve replacement. However, patients with APS have shown an increased perioperative morbidity and mortality. Intracardiac thrombosis, 
although a rare complication, can cause pulmonary and systemic emboli [98].

\subsubsection{Aspirin and APS}

The primary prophylaxis of thrombosis with low dose aspirin $(81 \mathrm{mg}$ ) in asymptomatic, persistently antiphospholipid antibody (APL)-positive individuals was not beneficial when compared to placebo [99]. SLE patients with persistent positive lupus anticoagulant (LA) antibody are at high risk of thrombosis, and primary prophylaxis with low-dose aspirin and hydroxychloroquine is recommended [100].

\subsubsection{Ankylosing Spondylitis (AS)}

It is a chronic inflammatory condition that usually affects young men, mainly affecting the spine and the sacroiliac joints and, to lesser extent, the peripheral joints. Cardiac dysfunction and pulmonary disease are well known and commonly reported extra-articular manifestation associated with ankylosing spondylitis (AS). The cardiac manifestations were reported in around $2-10 \%$ [101], and it may reach up to $30 \%$ [102] of patients with AS - mostly conduction defects and aortic insufficiency [101]. The cardiac manifestation is mostly observed in patients with long-term AS and peripheral joint involvement [103]. AS has also been reported to be specifically associated with aortitis, aortic valve diseases, conduction disturbances, cardiomyopathy, and CAD. There is no difference between the type of rheumatic therapy and its use among patients with AS, who have myocardial infarction versus who does not [101].

\subsubsection{Aortic Involvement}

It was first described in 1973 AD by Bulkley and Roberts during autopsy examination of patients with AS that had congestive heart failure due to severe aortic regurgitation [104]. It is an important topic, because if patients with AS developed chest pain, you should rule out aortic dissection.

Prevalence: Echocardiographic evidence of aortic regurgitation was mostly mild and was observed in around $3-13 \%$ of patients with AS
[60]. Positive HLA-B27 patients with aortic regurgitation around half of them do not have clinical features of rheumatic disease [105].

Pathology: Arteritis around the aortic root and valve due to inflammatory process with platelets aggregation lead to tissue thickening [104]. There is fibrous growth of the intimal layer that leads to aortic root dilatation [104]. Increase in stiffness of the aorta and decreased global myocardial performance are features of AS and correlate with the disease activity and its duration [106].

Diagnosis: Echocardiography: TEE showed aortic root thickening, increased stiffness, dilatation, and nodularities of the aortic cusps. The first two were the most common findings [107]. Valve regurgitation was seen in around half of the patients [107].

\subsubsection{Myocardial Involvement}

Prevalence: Diastolic dysfunction was found at the rate of $20 \%$ [108] ranging to 50\% [109], while systolic dysfunction was affected less than that in around $18 \%$ of AS patients [110].

Pathology: It was found to have an increase in myocardial inflammation and the connective tissue/myocyte rate, which will give the picture of the increase in diffuse interstitial connective tissue [110].

Presentation: Diastolic dysfunction in AS is usually not severe enough to cause diastolic heart failure [111]. Rarely, were LV systolic dysfunction and hypertrophy reported in the absence of significant aortic regurgitation [48].

\subsubsection{Conduction Abnormalities}

It is the most common finding in AS patients, and it usually precedes the other cardiac findings [102].

Prevalence: Conduction abnormalities were observed in around 2-20\% of AS patients [60]. Around half of the positive HLA-B27 patients with conduction abnormalities do not have clinical features of rheumatic disease [105].

Pathology: Inflammatory process leads to damage of the interventricular septum wall, and AV node dysfunction is secondary to the compromise of the arterial supply to the AV node [112]. 
Another factor is the autonomic nervous system abnormalities that can lead to conduction defects and arrhythmias at the end [113].

Associations: Disease duration is associated with the prolongation of the PR and the QRS intervals [112]. Conduction abnormalities occur more frequently in patients with positive HLAB27 [105].

\section{Types:}

1. Supraventricular extrasystoles and ventricular extrasystoles are very common findings among AS patients [102].

2. Prolonged QRS interval in about $29.2 \%$ of AS patients [112].

3. First-degree atrioventricular (AV) block in around $4.6 \%$ of AS patients [112].

4. Complete right bundle branch block (RBBB) in around $0.8 \%$ of AS patients [112].

5. Left anterior hemiblock $0.8 \%$ of AS patients [112].

\subsubsection{Psoriatic Arthritis}

The increased risk of clinical and subclinical CVD is mostly due to accelerating atherosclerosis, and the incidence of mortality in CAD was similar to that of RA [114]. Patients with psoriatic arthritis have higher occurrences of CVD risk factors and CAD, peripheral vascular disease, and congestive heart failure [115].

\subsubsection{Arrhythmias}

Incidence: Patients with psoriasis were found to have higher risk of developing arrhythmia than the normal population at the rate of 15.41 per 1000 person-years, and this was even higher among patients with psoriatic arthritis [116].

\subsubsection{CAD:}

Incidence: The incidences of myocardial infarction is 5.13 per 1000 person-years, while it is 5.13 for severe psoriasis, which is higher than the general population [7]. The new events of heart failure were higher among psoriasis patients, especially among the severe psoriasis group than the general population [117].
Associations: Severe psoriasis is associated rationally with a higher risk of death, specifically cardiovascular being the most common cause [118]. CAD is associated with young patients [7, 119], psoriatic arthritis [119], and/or severe psoriasis $[7,119]$. Severe psoriasis has higher risk of CAD and stroke [119].

Pathology: Metabolic diseases, such as obesity and diabetes mellitus, are more among psoriasis patients, which may play a role in the development of atherosclerosis in addition to the inflammatory process [120].

Prevention: Treatment with methotrexate and TNF alpha inhibitors therapy appears to lower the rates of CAD among patients with psoriasis [120].

\subsubsection{Systemic Vasculitis}

CVD is significantly involved in different types of systemic vasculitis, ranging from large to small vessel vasculitis (see Chap. 20 on "Vasculitis and Rheumatology").

\subsection{The Accelerated Atherosclerosis Effects on CAD in Rheumatologic Diseases}

This can be called an immune system-mediated inflammatory process as the immune cells can be found within atherosclerotic plaques, and inflammation activates this process.

(Table 16.5 shows the major contributing factors for atherosclerosis in different rheumatologic diseases).

\subsection{Metabolic Syndrome and Rheumatological Diseases}

The concept of metabolic syndrome was first recognized by Raven when he discussed that insulin resistance has a central role in type $2 \mathrm{DM}$, hypertension, and CAD [121]. Later, it became known as metabolic syndrome. The major components 
Table 16.5 : Atherosclerosis in rheumatologic diseases

\begin{tabular}{|c|c|c|}
\hline Disease & \multicolumn{2}{|l|}{ Contributed factors } \\
\hline All & \multicolumn{2}{|c|}{$\begin{array}{l}\text { - Active prolonged inflammatory process. } \\
\text { - Vascular endothelial dysfunction and injury. } \\
\text { - } \uparrow \text { Oxidized LDL (oxLDL) engulfed by macrophages to form foam cells } \\
\text { - Immune dysregulation by } \uparrow \text { CD4+ T cells that lack surface CD28 molecule (CD4 + CD28-), } \\
\text { which infiltrate the atherosclerotic plaques and display a high pro-inflammatory and tissue- } \\
\text { damaging potential; this promotes vascular injury. } \\
\text { - } \uparrow \text { Beta } 2 \text { glycoprotein I (B2GPI) is present along with CD4 lymphocytes in the plaque cells which } \\
\text { increase the lesion area. } \\
\text { - The plague secretes interleukins, tumor necrosis factor- } \alpha \text { (TNF), and platelet-derived growth } \\
\text { factor for more expansion of the lesion. } \\
\text { - } \uparrow \text { Anti-oxLDL, (aCL) antibodies, anti- } \beta 2 \mathrm{GPI} \text { antibodies when there is extensive atherosclerosis. }\end{array}$} \\
\hline Disease & Contributed factors & \multirow{5}{*}{$\begin{array}{l}\text { Subclinical detection } \\
\text { Preclinical atherosclerosis can be } \\
\text { detected by: } \\
\text { 1. B mode-carotid ultrasound: } \\
\text { - IMT (intimal medial } \\
\text { thickness). } \\
\text { - See atherosclerotic plague by } \\
\text { echolucency and calcific } \\
\text { acoustic shadowing. } \\
\text { 2. CT scan of coronary arteries: } \\
\text { - Presence of calcification. } \\
\text { - Extent of calcification. } \\
\text { 3. Arterial stiffness: } \\
\text { • Pulse wave velocity (PWV). } \\
\text { - Pulse wave analysis (PWA). } \\
\text { 4. Elevated CRP. }\end{array}$} \\
\hline RA & $\begin{array}{l}\text { - Endothelial dysfunction. } \\
\text { - Traditional risk factors. } \\
\text { - Depletion of endothelial progenitor cells. }\end{array}$ & \\
\hline SLE & $\begin{array}{l}\text { - Traditional risk factors. } \\
\text { - Depletion of endothelial progenitor cells. } \\
\text { - Inflammation. } \\
\text { - Metabolic changes in SLE: Renal dysfunction and early } \\
\text { menopause. } \\
\text { - Antiphospholipid antibodies. }\end{array}$ & \\
\hline APS & $\begin{array}{l}\text { - Possible involvement of antiphospholipid antibodies } \\
\text { (APL) in the pathogenesis of atherosclerosis. } \\
\text { - Positive APL is associated with arterial atherosclerosis } \\
\text { which will develop into thrombosis at coronary, carotid, } \\
\text { and lower peripheral arteries. } \\
\text { - Positive lupus anticoagulant (LA) is associated with } \\
\text { venous thrombosis. }\end{array}$ & \\
\hline $\begin{array}{l}\text { Systemic } \\
\text { sclerosis }\end{array}$ & $\begin{array}{l}\text { - Endothelial injury and its activation can lead to loss of } \\
\text { vasomotor function and vasoconstriction. } \\
\text { - Myofibroblasts develop from activated vascular muscles } \\
\text { and cause thickening of the intima, lumen narrowing, and } \\
\text { irreversible fibrosis. } \\
\text { - It may also induce formation of intravascular thrombosis. }\end{array}$ & \\
\hline $\begin{array}{l}\text { Ankylosing } \\
\text { spondylitis }\end{array}$ & $\begin{array}{l}\text { - There are very limited studies. } \\
\text { - Inflammation is a possible contributed risk. } \\
\text { - Endothelial dysfunction. }\end{array}$ & $\begin{array}{l}\text { - No difference in IMT compared } \\
\text { with the general population. } \\
\text { - Impaired flow-mediated } \\
\text { dilatation and coronary flow } \\
\text { reserve. }\end{array}$ \\
\hline Vasculitis & $\begin{array}{l}\text { - There is inflammatory cells infiltration in the layers of } \\
\text { arterial wall. }\end{array}$ & - Variable. \\
\hline
\end{tabular}

of metabolic syndrome include dyslipidemia, central obesity, insulin resistance, and hypertension [122]. The major components are not occurring concurrently; as it was found that insulin sensitivity will predict the increase in waist circumference (obesity), and the latter will predict the remaining components, e.g., dyslipidemia and hypertension [123]. The adipose tissue is acting as endocrine organ by the secretion of the pro-inflammatory factors called adipokines.
Insulin resistance has a role in the development of CVD (probably due to the adipokines from the adipose tissue) [124] as it has a role in the enhancement of vascular inflammation and endothelial dysfunction [125]. Different adipokines have been recognized in metabolic syndrome with rheumatic diseases, and their effects were emphasized (see Table 16.6).

Patients with rheumatic diseases are under the pressure of chronic inflammation mainly with 
Table 16.6 The effects of different adipokines on rheumatologic diseases [154]

\begin{tabular}{|c|c|c|c|c|}
\hline \multirow[b]{2}{*}{ Rheumatic disease } & \multicolumn{4}{|l|}{ Adipokines } \\
\hline & Leptin & Adiponectin & Visfatin & Resistin \\
\hline RA & $\uparrow$, pro-inflammatory & $\uparrow$, Synovitis & $\begin{array}{l}\uparrow, \text { Radiographic joint } \\
\text { damage }\end{array}$ & $\begin{array}{l}\uparrow, \text { Disease activity } \\
\text { and joint } \\
\text { destruction }\end{array}$ \\
\hline PsA & Controversial & Controversial & Controversial & - \\
\hline PsA & - & - & & - \\
\hline AS & $\begin{array}{l}\text { Marker of disease } \\
\text { activity?? }\end{array}$ & - & Controversial & - \\
\hline Gout & - & - & - & - \\
\hline $\mathrm{OA}$ & $\begin{array}{l}\uparrow, \text { cartilage } \\
\text { destruction }\end{array}$ & Controversial & $\begin{array}{l}\uparrow, \text { degradation of } \\
\text { collagen }\end{array}$ & - \\
\hline
\end{tabular}

RA and SLE. Many patients with rheumatic diseases - mainly RA, SLE, and AS-have been diagnosed with metabolic syndrome [14-16].

Here, we will discuss the rheumatic diseases and its relationship with metabolic syndrome.

\subsubsection{RA}

It was initial to associate insulin sensitivity to be lower in RA patients compared to osteoarthritis patients [126]. Later, it was found that the main factors of insulin resistance in RA are obesity and disease activity [127]. The prevalence of metabolic syndrome among RA patients ranges from $44 \%$ to $53 \%[15,128]$. Such patients were found to have higher disease activity than those without metabolic syndrome with low level of highdensity lipoprotein cholesterol [15]. Its presence is associated with higher systemic inflammatory marker and glucocorticoids use [129]. Patients with RA, who were diagnosed with metabolic syndrome, were found to have higher risk of coronary artery calcification [128].

\subsubsection{SLE}

Non-diabetic patients with SLE were found to have significant decrease in sensitivity to insulin, and around $18 \%$ of them were diagnosed with metabolic syndrome [130]. The prevalence of metabolic syndrome among SLE patients ranges from $16 \%$ to $32.4 \%$ [14, 131, 132]. SLE patients have higher fasting insulin level, and cardiovascular risk factors were also elevated among the last group [133]. Metabolic syndrome was associated with higher level of C-reactive protein, homocysteine, lipoprotein, and cholesterol [14] . Metabolic syndrome and CVD among SLE patients were associated with prolonged SLE duration and increased cumulative organ damage [131]. Lupus nephritis, high corticosteroid doses, Korean and Hispanic ethnicity were associated with metabolic syndrome in SLE patients [132]. The use of hydroxychloroquine was associated with protective effect of CVD [131].

\subsubsection{AS}

The prevalence of metabolic syndrome among AS is around $45.8 \%$ [16], whereas low AS disease activity is not associated with accelerated atherosclerosis [134].

\subsubsection{Psoriasis}

Psoriasis is associated with DM. The prevalence of DM was higher with severe psoriasis than mild psoriasis in the rate of $7.1 \%$ vs. $4.4 \%$, respectively [135]. The prevalence of metabolic syndrome among psoriatic patient ranges from $15 \%$ to $35.5 \%$ [136-138]. Psoriatic patients are prone to the development of the main components of metabolic syndrome (e.g., DM and hypertension) [139]. Treating psoriasis was found to be associated with improvement in the metabolic risk biomarkers, such as high-sensitivity CRP, adiponectin, and the oral glucose tolerance test [140]. 


\subsubsection{Gout}

The initial association of gout with metabolic syndrome was with the close association of hyperurecemia and the components of metabolic syndrome (e.g., hypertension, insulin resistance, and obesity) was noted [141]. Elevated uric acid levels among gout patients can be associated with insulin resistance since renal clearance is inversely related with insulin resistance [142]. The prevalence of metabolic syndrome among gout patients ranges from $44 \%$ to $88 \%$ [143-145].

\subsection{The Various Medications that Are Being Used in the Management of Rheumatologic Disease that Have Variable Effects on CAD}

It is important to mention these factors because managing clinicians may not pay attention to these effects as they focus mainly on the activity of the rheumatologic disease.

\subsubsection{NSAIDs ${ }^{3}$}

- The risks of major cardiovascular eventssuch as myocardial infarction, stroke, and death-appear to increase to a similar degree by the use of most nonselective NSAIDs at high doses. The exception is naproxen, which does not increase such risk [146].

- All of the COX-2 selective inhibitors (coxibs) appear to increase the risk of ischemic cardiovascular disease in a dose-dependent fashion. Recent data showed that naproxen, celecoxib, and ibuprofen did not differ in the risk of the cardiovascular mortality, but naproxen was less than the last two for the risk of the gastrointestinal bleeding [147]. Certain COX-2

\footnotetext{
${ }^{3}$ The association of nonsteroidal anti-inflammatory drugs (NSAIDs) with cardiovascular morbidity and mortality in patients with RA is still controversial.
}

inhibitors are associated with twofold increase in CAD risk.

- COX inhibition leads to CAD with two possible mechanisms:

- It can interfere with normal platelet and endothelial vasodilator functions.

- It can cause hypertension.

- All (NSAIDs) can increase blood pressure in both normotensive and hypertensive individuals. Its use may reduce the effect of all antihypertensive drugs except calcium channel blockers.

(Figure 16.1 summarizes the effects of NSAIDs on the cardiovascular system)

\subsubsection{Glucocorticoids (GC)}

This medication is known to have serious noxious effects by increasing blood pressure, insulin resistance, body weight, and fat distribution. There is an excess risk of cardiovascular morbidity and mortality when the drug is used in high cumulative doses and for a long duration. There is $68 \%$ of increased risk of myocardial infarction among RA patients treated with GCs [148]. Cushing disease is associated with accelerated atherosclerotic vascular disease [149].

\subsubsection{Methotrexate}

Many studies have demonstrated that its use has been associated with a beneficial reduction in CVD events among patients with systemic inflammation diseases primarily from RA [49]. It is known to decrease homocysteine level. RA patients who used methotrexate have lower LDL levels, significant increase in mean HDL, and decrease in carotid artery intima-media thickness, compared with baseline values.

\subsubsection{TNF Biologic DMARDs}

- A large study showed significant reduction in fatal and nonfatal CVD outcomes associated 


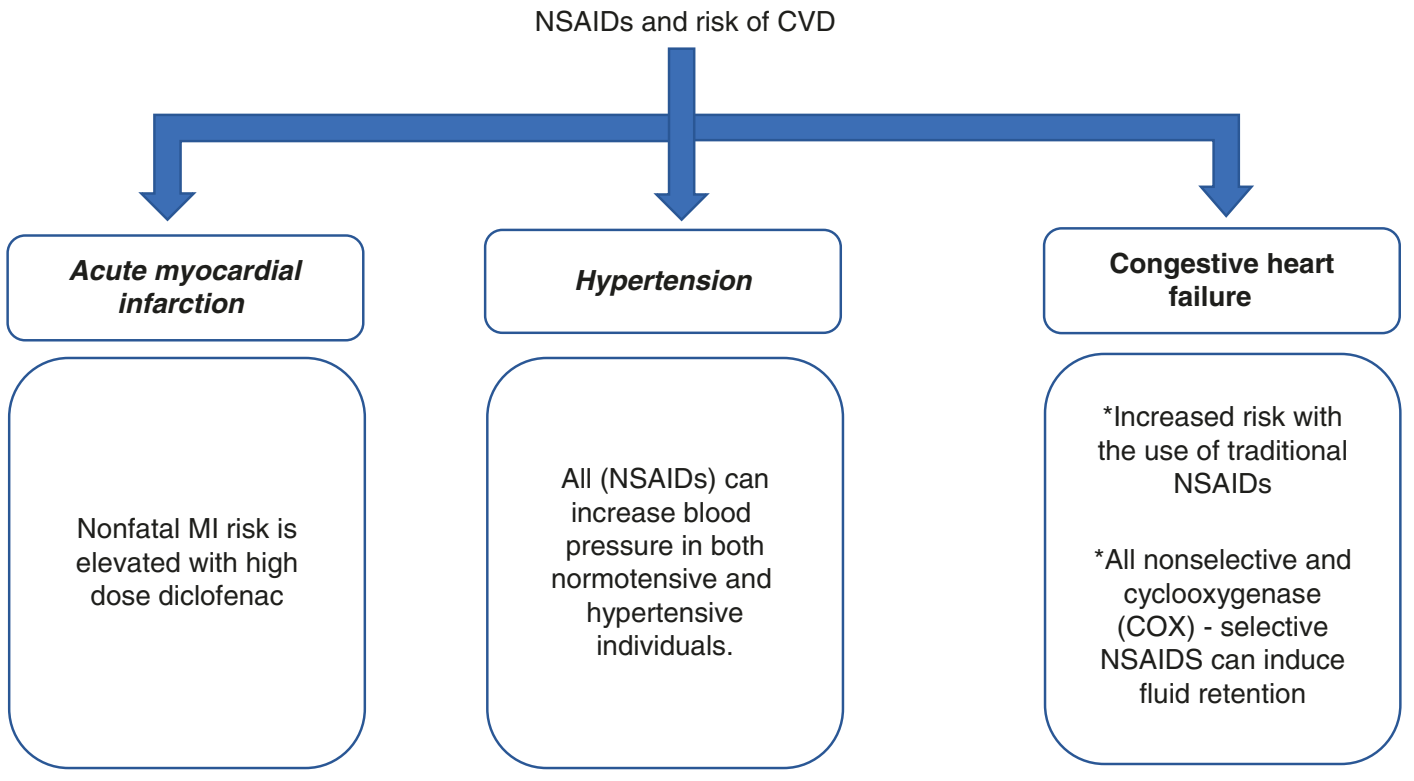

Fig. 16.1 NSAIDs and risk of CVD

with TNF inhibitors, but this remains controversial.

- The cardiovascular benefit of TNF inhibitors may be limited to patients with RA whose synovitis responds to these agents. Patients whose disease activity was reduced by TNF inhibitor therapy within the first 6 months of treatment had markedly decreased risk of myocardial infarction compared with those who continued to have active disease.

- It was associated with a significant increase in both total cholesterol and HDL with no change in regard to the atherogenic index [150].

\subsubsection{Non-TNF Biologic DMARDs}

- Rituximab has no significant effect on CVD, with no positive outcome on lipid profile or endothelial dysfunction.

- Tocilizumab is associated with beneficial low CRP after early introduction, but it has unclear worse effect regarding elevation of total cholesterol, LDL [151, 152] when used for years, even though it does not increase CVD events. Tofacitinib is also associated with increased level of LDL [153].
In summary, for the prevention of CAD in rheumatologic diseases, we should do the following:

- Traditional CAD risk factors control.

- Early diagnosis and management of CAD.

- Long follow-up for CAD complications.

- Early diagnosis and management of rheumatologic disease with strict control of the disease activity.

Acknowledgments The authors would like to thank Maged Al-Ammari, MD, for his contributions to this chapter in the previous edition.

\section{Appendix 1}

\section{Note about tables and figures}

* Diagnostic markers of CVD in rheumatologic disease (including $\mathrm{CAD}$ ): we have a table that summarizes the workup needed for the detection of CVD in each group of patients with rheumatologic disease (Table 16.A.1).

* Management and control of CVD risk factors (Including CAD): The control and the prevention of the risk factors for CVD and what we also call traditional risk factors for CAD are summarized in Table 16.A.2. 
Table 16.A.1 Diagnostic markers of CVD in rheumatologic disease

\begin{tabular}{|c|c|c|}
\hline \multirow[b]{2}{*}{ AIRDs } & \multicolumn{2}{|c|}{ Diagnosis of CVD } \\
\hline & Disease & Investigation \\
\hline \multirow[t]{3}{*}{ RA } & MI & $\begin{array}{l}\text { - ECG and cardiac enzymes: Mainly troponins and CK MB. } \\
\text { - Echocardiogram. }\end{array}$ \\
\hline & $\begin{array}{l}\text { Congestive } \\
\text { heart failure }\end{array}$ & $\begin{array}{l}\text { - Echocardiogram. } \\
\text { - Chest X-rays. } \\
\text { CBC, serum electrolytes, BUN, creatinine, liver function test, and fasting } \\
\text { blood sugar. } \\
\text { - Elevated B-type natriuretic peptide (BNP) levels are not specific for left } \\
\text { ventricular systolic dysfunction, and may be reduced by concomitant diuretic } \\
\text { and angiotensin-converting enzyme inhibitor therapy, limiting sensitivity } \\
\text { [155] } \\
\text { Exercise stress tests. }\end{array}$ \\
\hline & $\begin{array}{l}\text { Peripheral } \\
\text { arterial disease }\end{array}$ & $\begin{array}{l}\text { - Clinical investigation of arterial stiffness to look for incompressibility and } \\
\text { obstruction and performing: } \\
\text { - PWV: Pulse wave velocity. } \\
\text { - PWA: Pulse wave analysis. } \\
\text { - Ankle-brachial systolic pressure index (ABI), } \\
\text { - Exercise testing (ABI) if rest (ABI) is normal. } \\
\text { - Contrast arteriography is the gold standard. }\end{array}$ \\
\hline \multirow[t]{4}{*}{ SLE } & $\begin{array}{l}\text { - Pericardium: } \\
\text { Mostly } \\
\text { asymptomatic, } \\
\text { pericarditis or } \\
\text { effusion. }\end{array}$ & $\begin{array}{l}\text { - ECG findings: Diffuse ST-elevation and T-wave abnormalities. } \\
\text { - Pericardiocentesis if significant pericardial effusion, fever (to rule out } \\
\text { concomitant infections) or failed medical treatment. } \\
\text { - Low antinuclear antibodies (ANA), phagocytic cells containing nuclei (LE } \\
\text { cells), low complement levels, and immune complexes in effusion. }\end{array}$ \\
\hline & $\begin{array}{l}\text { Myocardium: } \\
\text { Mainly } \\
\text { myocarditis }\end{array}$ & $\begin{array}{l}\text { - ECG findings: Prolonged PR intervals, ST and T-wave abnormalities. } \\
\text { - Echocardiography. } \\
\text { - MRI. } \\
\text { - Myocardial biopsy. }\end{array}$ \\
\hline & $\begin{array}{l}\text { Endocardium } \\
\text { and valves }\end{array}$ & $\begin{array}{l}\text { - Echocardiography if a new murmur is detected or changing in cardiac } \\
\text { function. } \\
\text { - Blood culture and echocardiography if fever or new heart murmur. } \\
\text { - Transesophageal Doppler echocardiography produces high-resolution images } \\
\text { of the cardiac valves and is superior to transthoracic echocardiography in the } \\
\text { detection of valve abnormalities. } \\
\text { - Libman-sacks endocarditis is typically asymptomatic. However, the verrucae } \\
\text { can fragment and produce systemic emboli, and infective endocarditis can } \\
\text { develop on already damaged valves [156].. }\end{array}$ \\
\hline & $\begin{array}{l}\text { Conduction } \\
\text { defects }\end{array}$ & $\begin{array}{l}\text { - Preconception or early prenatal testing for anti-Ro/SSA and anti-La/SSB } \\
\text { antibodies and periodic monitoring for the development of heart block in the fetus. } \\
\text {. }\end{array}$ \\
\hline $\begin{array}{l}\text { Systemic } \\
\text { sclerosis }\end{array}$ & $\begin{array}{l}\text { Pulmonary } \\
\text { arterial } \\
\text { hypertension } \\
\text { Myocardium }\end{array}$ & $\begin{array}{l}\text { - ECG: Look for tachyarrhythmia. } \\
\text { - Chest X-ray. } \\
\text { - Doppler echocardiogram: } \\
\text { - Rhythm. } \\
\text { - Conduction disturbance. } \\
\text { - Cardiac chambers and valves (morphology and function). } \\
\text { - Pulmonary arterial pressure. } \\
\text { - Cardiac pulmonary stress test. } \\
\text { - Cardiac catheterization for better diagnosis of pulmonary hypertension. } \\
\text { - MRI. } \\
\text { - Nuclear studies of myocardial function and perfusion. }\end{array}$ \\
\hline AS \& PsA & $\begin{array}{l}\text { Different } \\
\text { CVDs }\end{array}$ & $\begin{array}{l}\text { - Clinical assessment. } \\
\text { - ECG. } \\
\text { - Cardiac enzymes. } \\
\text { - Echocardiogram. }\end{array}$ \\
\hline
\end{tabular}


Table 16.A.1 (continued)

\begin{tabular}{|c|c|c|}
\hline \multirow[b]{2}{*}{ AIRDs } & \multicolumn{2}{|c|}{ Diagnosis of CVD } \\
\hline & Disease & Investigation \\
\hline \multirow[t]{6}{*}{ APS } & IHD & $\begin{array}{l}\text { - Clinical assessment. } \\
\text { - ECG. } \\
\text { - Cardiac enzymes. }\end{array}$ \\
\hline & $\begin{array}{l}\text { Valvular } \\
\text { disease }\end{array}$ & $\begin{array}{l}\text { - Clinical: Asymptomatic regurgitation. } \\
\text { - Echocardiogram: Vegetation and marked thickening. }\end{array}$ \\
\hline & $\begin{array}{l}\text { Pseudo- } \\
\text { endocarditis }\end{array}$ & $\begin{array}{l}\text { - Clinical: Fever, murmur, and splinter hemorrhage. } \\
\text { - Echocardiogram with the presence of mitral valve nodules and mitral } \\
\text { regurgitation. } \\
\text { - High APL titer. } \\
\text { - Blood culture is negative for infection. }\end{array}$ \\
\hline & $\begin{array}{l}\text { Peripheral } \\
\text { artery disease }\end{array}$ & - Ankle-brachial index at lower extremities is abnormal. \\
\hline & DVT & $\begin{array}{l}\text { - Clinical assessment. } \\
\text { - Duplex ultrasound. } \\
\text { - D-dimer for exclusion in low probability cases.. }\end{array}$ \\
\hline & $\begin{array}{l}\text { Intracardiac } \\
\text { thrombus }\end{array}$ & $\begin{array}{l}\text { - Not common and misdiagnosed. } \\
\text { - Clinical: Angina-like pain. } \\
\text { - Exercise test: Positive. } \\
\text { - Angiogram: Normal coronary arteries. }\end{array}$ \\
\hline $\begin{array}{l}\text { Inflammatory } \\
\text { myopathies }\end{array}$ & CVDs are rare & $\begin{array}{l}\text { - ECG: Conduction defects and arrhythmia. } \\
\text { - Specific marker is the level of cardiac isoform troponin-I. } \\
\text { - Creatine kinase (CK)-MB is not a specific cardiac marker, so it is not helpful. }\end{array}$ \\
\hline Vasculitis & $\begin{array}{l}\text { According to } \\
\text { the type }\end{array}$ & $\begin{array}{l}\text { - ECG and echocardiogram. } \\
\text { - Contrast-enhanced cardiac MRI. } \\
\text { - BNP. } \\
\text { - ANCA. }\end{array}$ \\
\hline
\end{tabular}

Table 16.A.2 Management and control of CVD risk factors [157]

\begin{tabular}{|c|c|}
\hline $\begin{array}{l}\text { Health } \\
\text { parameters }\end{array}$ & Maintenance \\
\hline Dyslipidemia & $\begin{array}{l}\text { - Annual lipid profile screening is recommended. } \\
\text { - Statin use decreases TC and LDL levels, which lower the risk of cardiovascular events; give if } \\
\text { it is indicated. } \\
\text { - In high-risk patients who use statins, the goal of LDL-C level: }<70 \mathrm{mg} / \mathrm{dL} \text {. . }\end{array}$ \\
\hline $\mathrm{DM}$ & $\begin{array}{l}\text { - Monitoring of blood glucose (fasting and random). } \\
\text { - Annual screening of hemoglobin A1c in patients with active disease and chronic corticosteroid use. } \\
\text { - Treatment of DM as guidelines. }\end{array}$ \\
\hline Hypertension & $\begin{array}{l}\text { - Early blood pressure monitoring when there is a risk from medication. } \\
\text { - Regular monitoring of blood pressure and start treatment as guidelines. } \\
\text { - Control level of blood pressure, the goal: }<140 / 90 \mathrm{mmHg} \text {. }\end{array}$ \\
\hline Smoking & $\begin{array}{l}\text { - Cessation is strongly recommended to improve disease activity and therapy effectiveness of } \\
\text { RA, and its benefit on lowering CVD events is probable. }\end{array}$ \\
\hline Obesity & $\begin{array}{l}\text { - Regular monitoring of BMI. } \\
\text { - Waist to hip ratio. } \\
\text { - Encouragement of healthy diet. } \\
\text { - Body mass index goal: } 18.5-24.9 \mathrm{~kg} / \mathrm{m}^{2} \text {. } \\
\text { - Waist circumference goal: Women } 35 \text { inches }(89 \mathrm{~cm}) \text {, men } 40 \text { inches }(102 \mathrm{~cm}) \text {. }\end{array}$ \\
\hline $\begin{array}{l}\text { Physical } \\
\text { activity }\end{array}$ & Goal: At least 30 min per day, minimum 3-4 times a week \\
\hline
\end{tabular}


* Preventive tips for using common medications in rheumatologic disease: As we recognize the numerous and various medications that are being used in the management of rheumatologic diseases that are being associated with adverse effects on the $\mathrm{CV}$ system and CAD so here we tried to have a summary of preventive tips to use while using them in those patients as shown in Table 16.A.3.

* The use of aspirin: there are no specific rules for its use in rheumatologic disease as the rules applied in those patients are the same as the general population. Figure 16.2 is a simple diagram showing the approach to use it.

* The use of statins: There are no specific rules for its use in rheumatologic disease as the rules applied in those patients are the same as the general population. We have here a simple diagram based on the latest guidelines from the American Heart Association (AHA) that was released in 2013 (Fig. 16.3).

Table 16.A.3 Medications of rheumatologic disease and the preventative measures

\begin{tabular}{|c|c|c|}
\hline Medication & Disease & Effects on CVD \\
\hline Glucocorticoids & $\begin{array}{l}\text { RA } \\
\text { SLE }\end{array}$ & $\begin{array}{l}\text { - Reduced doses will lower the risk of CAD. } \\
\text { - Calcium and vitamin D should be given. } \\
\text { - Since the risk is dose-dependent, it is a must to keep the duration of using } \\
\text { steroids as short as possible and the dose as minimal as possible. } \\
\text { - A close surveillance of blood pressure and modification of antihypertensive } \\
\text { regimens is recommended when the patient is hypertensive and is receiving } \\
\text { moderate to high doses of GCs. } \\
\text { - Increased cardiovascular disease was associated with glucocorticoid use at doses } \\
\geq 7.5 \mathrm{mg} \text { /day of prednisone or its equivalent [158]. }\end{array}$ \\
\hline Methotrexate & RA & $\begin{array}{l}\text { - Folic acid supplementation to correct homocysteine level. } \\
\text { - It is advisable to continue using it as indicated as a DMARD. } \\
\text { - Its CVD benefit is not fully approved, but a definitive result will come out from } \\
\text { further studies which may prove the hypothesis of CVD as an inflammatory } \\
\text { mechanism, and it can be beneficial in chronic CVD management. }\end{array}$ \\
\hline TNF blockers & $\begin{array}{l}\text { RA } \\
\text { AS }\end{array}$ & $\begin{array}{l}\text { - Annual lipid screening is recommended when the risk of lipid disturbance is } \\
\text { there. } \\
\text { - Inpatients with RA, it is recommended to continue using TNF inhibitors as } \\
\text { biologic DMARD therapy. } \\
\text { - Anti-TNF biologic (infliximab) is not recommended in patient with NYHA class } \\
3 \text { or } 4 \text { cardiac failure with an ejection fraction of } \leq 50 \% \text { due to a worsening effect } \\
\text { of infliximab on the cardiac function. } \\
\text { - Check pulse wave velocity and analysis for possible transient improvement of } \\
\text { vascular morbidity. } \\
\text { - TNF blockers may decrease CVD involvement and atherosclerosis in ankylosing } \\
\text { spondylitis, but no strong evidence. }\end{array}$ \\
\hline Non-TNF & RA & $\begin{array}{l}\text { - More, larger studies are needed to clear the risky-beneficial nature of these } \\
\text { medications and their effects over the CVD. }\end{array}$ \\
\hline NSAIDS & $\begin{array}{l}\text { RA } \\
\text { AS }\end{array}$ & $\begin{array}{l}\text { - Effective for pain management, but it is wise to be cautious about the } \\
\text { cardiovascular side effects of NSAIDs especially in patients with high CVD risk } \\
\text { factors. } \\
\text { - Extra caution regarding the dose, risk factors, and comorbidity status. }\end{array}$ \\
\hline Statins & SLE & $\begin{array}{l}\text { For primary and secondary prevention (as evident by the last AHA guidelines 2013) } \\
\text { [159] } \\
\text { - Anti-inflammatory effect. } \\
\text { - Lowering LDL-C and CRP. } \\
\text { - Antithrombotic effect. } \\
\text { - Immuno-modulating effect. }\end{array}$ \\
\hline Aspirin & $\begin{array}{l}\text { SLE } \\
\text { APS }\end{array}$ & $\begin{array}{l}\text { Should be indicated in SLE if no contraindication: } \\
\text { - History of CAD. } \\
\text { - Ongoing risk factors like HTN, DM, high cholesterol, and smoking. } \\
\text { - Prophylactic low-dose aspirin in patients with thrombosis-free and -positive } \\
\text { APL. }\end{array}$ \\
\hline
\end{tabular}


Table 16.A.3 (continued)

\begin{tabular}{|c|c|c|}
\hline Medication & Disease & Effects on CVD \\
\hline $\begin{array}{l}\text { Anticoagulation } \\
\text { therapy }\end{array}$ & APS & $\begin{array}{l}\text { - In patients with first event of venous thrombosis (INR: } 2.0-3.0 \text { ). } \\
\text { - In patients with recurrent venous or arterial thrombosis, give intensive therapy } \\
\text { (INR: } 3.0-4.0 \text { ). } \\
\text { - It is recommended to give antiplatelet therapy with anticoagulation therapy } \\
\text { (controversial). }\end{array}$ \\
\hline $\begin{array}{l}\text { Antimalarial } \\
\text { agents }\end{array}$ & $\begin{array}{l}\text { SLE } \\
\text { APS }\end{array}$ & $\begin{array}{l}\text { - Anti-inflammatory effect. } \\
\text { - Anticoagulant effect. } \\
\text { - For lipid profile improvement. } \\
\text { - Prophylactic dose in patients with thrombosis-free positive APL in APS. }\end{array}$ \\
\hline Cyclophosphamide & SLE & $\begin{array}{l}\text { - It is the standard treatment of severe SLE with organ involvement, e.g., } \\
\text { myocarditis. } \\
\text { - It is recommended to give pulse steroids and pulse cyclophosphamide. }\end{array}$ \\
\hline $\begin{array}{l}\text { Calcium channel } \\
\text { blockers }\end{array}$ & SSc & $\begin{array}{l}\text { - Nifedipine and Diltiazem use with caution as they are contraindicated in MI and } \\
\text { angina as they are causing reflex tachycardia. }\end{array}$ \\
\hline $\begin{array}{l}\text { Endothelin } \\
\text { receptor } \\
\text { antagonist }\end{array}$ & SSc & $\begin{array}{l}\text { - Bosentan for relieving dyspnea and improvement of } 6 \text { min walk test (6MWT) } \\
{[160] .}\end{array}$ \\
\hline $\begin{array}{l}\text { Prostacyclin } \\
\text { analogues }\end{array}$ & SSc & $\begin{array}{l}\text { - Iloprost for widening narrow blood vessels and better blood circulation. } \\
\text { - Ventavis inhaled solution for stage } 3 \text { or } 4 \text { pulmonary hypertension. }\end{array}$ \\
\hline Sidenafil & SSc & - For improvement of hemodynamics . \\
\hline
\end{tabular}

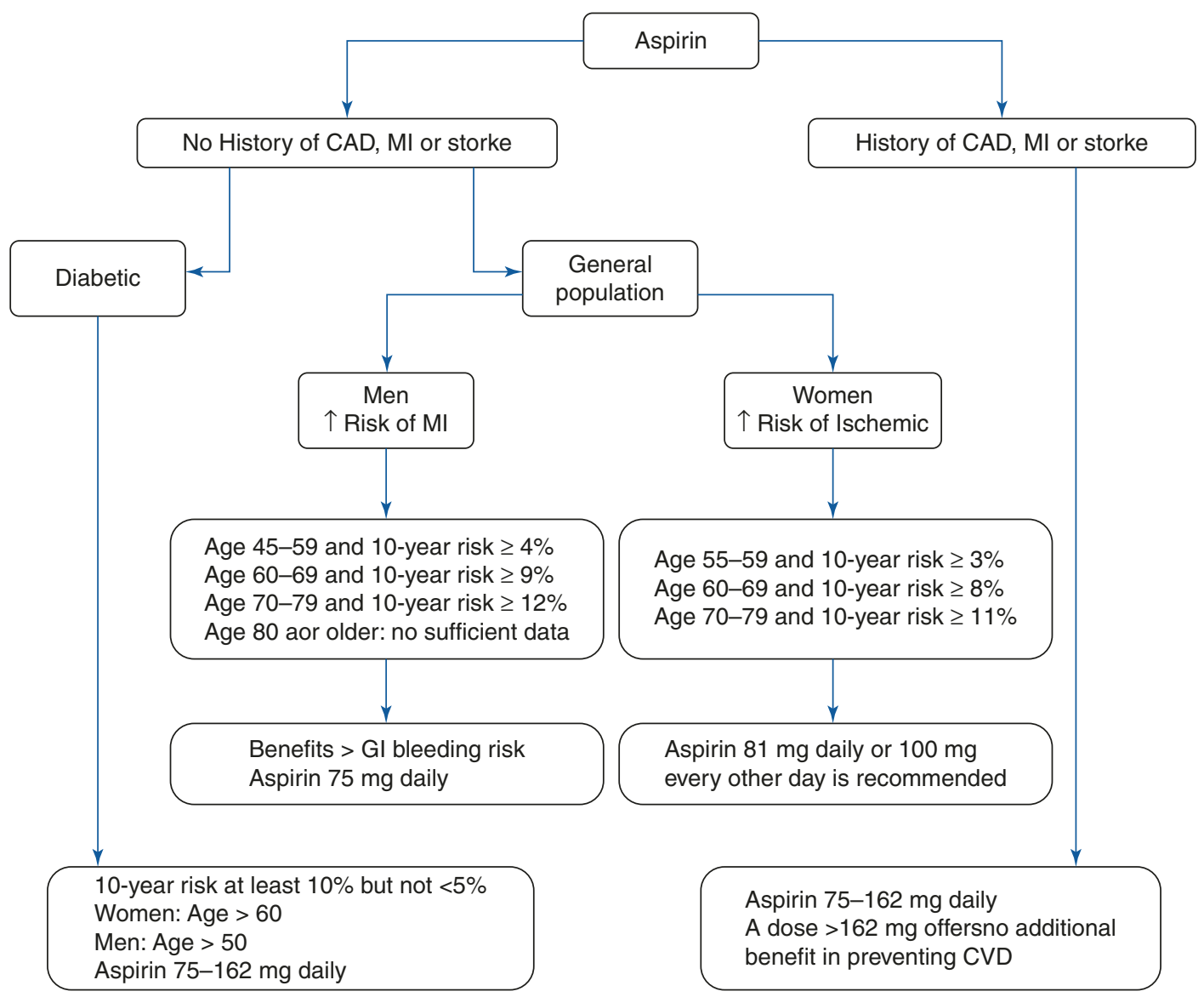

Fig. 16.2 The use of aspirin for primary and secondary prevention of CAD [161] 


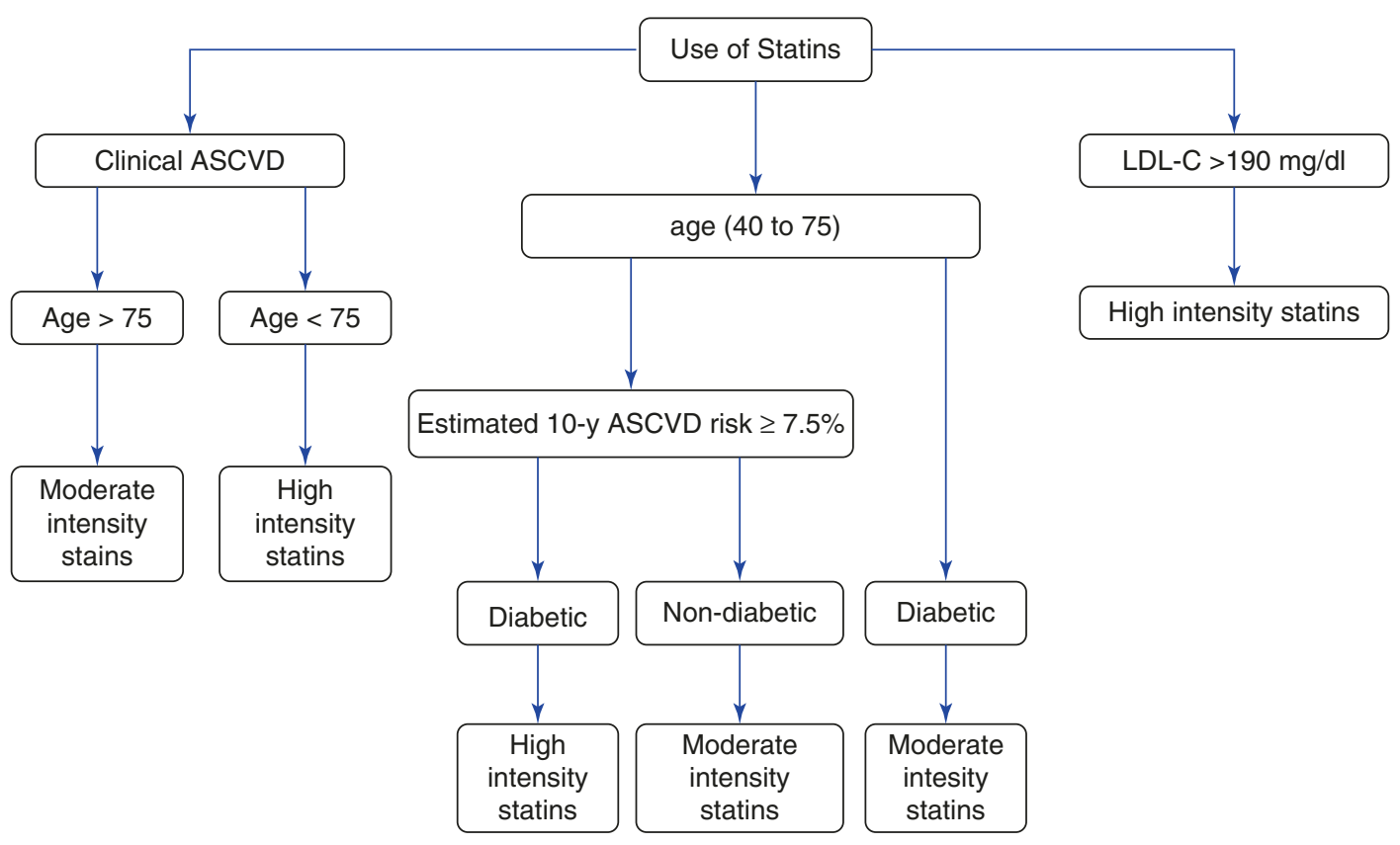

High Intensity Statins Therapy

- Atorvastatin 40-80 mg

- Rosuvastatin 20-40 mg

Moderate Intensity Statin Therapy

- Atorvastatin 10-20 mg

- Rosuvastatin 5-10 mg

- Simvastatin 20-40 mg

- Pravastatin 40-80 mg

- Lovastatin $40 \mathrm{mg}$

- Fluyastatin XL $80 \mathrm{mg}$

- Fluyastatin $40 \mathrm{mg}$

- Pitavastatin 2-4 mg

Fig. 16.3 The use of the statins for management of CAD [159]

\section{References}

1. Allanore Y, Meune C, Vonk MC, Airo P, Hachulla E, Caramaschi $\mathrm{P}$, et al. Prevalence and factors associated with left ventricular dysfunction in the EULAR scleroderma trial and research group (EUSTAR) database of patients with systemic sclerosis. Ann Rheum Dis. 2010;69(1):218-21.

2. Gowda RM, Khan IA, Sacchi TJ, Vasavada BC. Scleroderma pericardial disease presented with a large pericardial effusion---a case report. Angiology. 2001;52(1):59-62.

3. Levy PY, Corey R, Berger P, Habib G, Bonnet JL, Levy S, et al. Etiologic diagnosis of 204 pericardial effusions. Medicine. 2003;82(6):385-91.

4. Escalante A, Kaufman RL, Quismorio FP Jr, Beardmore TD. Cardiac compression in rheumatoid pericarditis. Semin Arthritis Rheum. 1990;20(3):148-63.

5. Zhang L, Zhu YL, Li MT, Gao N, You X, Wu QJ, et al. Lupus myocarditis: a case-control study from China. Chin Med J. 2015;128(19):2588-94.

6. Chu SY, Chen YJ, Liu CJ, Tseng WC, Lin MW, Hwang CY, et al. Increased risk of acute myocardial infarction in systemic sclerosis: a nationwide population-based study. Am J Med. 2013;126(11):982-8.

7. Gelfand JM, Neimann AL, Shin DB, Wang $\mathrm{X}$, Margolis DJ, Troxel AB. Risk of myocardial infarction in patients with psoriasis. JAMA. 2006;296(14):1735-41.

8. Goodson N. Coronary artery disease and rheumatoid arthritis. Curr Opin Rheumatol. 2002;14(2):115-20.

9. Petri M, Perez-Gutthann S, Spence D, Hochberg MC. Risk factors for coronary artery disease in patients with systemic lupus erythematosus. Am J Med. 1992;93(5):513-9. 
10. Chung CP, Oeser A, Avalos I, Gebretsadik T, Shintani A, Raggi P, et al. Utility of the Framingham risk score to predict the presence of coronary atherosclerosis in patients with rheumatoid arthritis. Arthritis Res Ther. 2006;8(6):R186.

11. Manzi S, Meilahn EN, Rairie JE, Conte CG, Medsger TA Jr, Jansen-McWilliams L, et al. Age-specific incidence rates of myocardial infarction and angina in women with systemic lupus erythematosus: comparison with the Framingham study. Am J Epidemiol. 1997;145(5):408-15.

12. Bruce IN, Urowitz MB, Gladman DD, Ibanez D, Steiner G. Risk factors for coronary heart disease in women with systemic lupus erythematosus: the Toronto risk factor study. Arthritis Rheum. 2003;48(11):3159-67.

13. Pons-Estel GJ, Gonzalez LA, Zhang J, Burgos PI, Reveille JD, Vila LM, et al. Predictors of cardiovascular damage in patients with systemic lupus erythematosus: data from LUMINA (LXVIII), a multiethnic US cohort. Rheumatology. 2009;48(7):817-22.

14. Chung CP, Avalos I, Oeser A, Gebretsadik T, Shintani A, Raggi P, et al. High prevalence of the metabolic syndrome in patients with systemic lupus erythematosus: association with disease characteristics and cardiovascular risk factors. Ann Rheum Dis. 2007;66(2):208-14.

15. Karvounaris SA, Sidiropoulos PI, Papadakis JA, Spanakis EK, Bertsias GK, Kritikos HD, et al. Metabolic syndrome is common among middle-toolder aged Mediterranean patients with rheumatoid arthritis and correlates with disease activity: a retrospective, cross-sectional, controlled, study. Ann Rheum Dis. 2007;66(1):28-33.

16. Malesci D, Niglio A, Mennillo GA, Buono R, Valentini G, La Montagna G. High prevalence of metabolic syndrome in patients with ankylosing spondylitis. Clin Rheumatol. 2007;26(5):710-4.

17. Maradit-Kremers H, Crowson CS, Nicola PJ, Ballman $\mathrm{KV}$, Roger VL, Jacobsen SJ, et al. Increased unrecognized coronary heart disease and sudden deaths in rheumatoid arthritis: a population-based cohort study. Arthritis Rheum. 2005;52(2):402-11.

18. Dhawan SS, Quyyumi AA. Rheumatoid arthritis and cardiovascular disease. Curr Atheroscler Rep. 2008;10(2):128-33.

19. Turesson C, O'Fallon WM, Crowson CS, Gabriel SE, Matteson EL. Extra-articular disease manifestations in rheumatoid arthritis: incidence trends and risk factors over 46 years. Ann Rheum Dis. 2003;62(8):722-7.

20. Gonzalez A, Maradit Kremers H, Crowson CS, Nicola PJ, Davis JM 3rd, Therneau TM, et al. The widening mortality gap between rheumatoid arthritis patients and the general population. Arthritis Rheum. 2007;56(11):3583-7.

21. Voskuyl AE, Zwinderman AH, Westedt ML, Vandenbroucke JP, Breedveld FC, Hazes JM. Factors associated with the development of vasculitis in rheumatoid arthritis: results of a case-control study. Ann Rheum Dis. 1996;55(3):190-2.
22. Hurd ER. Extraarticular manifestations of rheumatoid arthritis. Semin Arthritis Rheum. 1979;8(3):151-76.

23. Corrao S, Messina S, Pistone G, Calvo L, Scaglione R, Licata G. Heart involvement in rheumatoid arthritis: systematic review and meta-analysis. Int J Cardiol. 2013;167(5):2031-8.

24. Edwards MH, Leak AM. Pericardial effusions on anti-TNF therapy for rheumatoid arthritis--a drug side effect or uncontrolled systemic disease? Rheumatology. 2009;48(3):316-7.

25. Harney S, O'Shea FD, FitzGerald O. Peptostreptococcal pericarditis complicating antitumour necrosis factor alpha treatment in rheumatoid arthritis. Ann Rheum Dis. 2002;61(7):653-4.

26. Sweet DD, Isac G, Morrison B, Fenwick J, Dhingra V. Purulent pericarditis in a patient with rheumatoid arthritis treated with etanercept and methotrexate. CJEM. 2007;9(1):40-2.

27. Imazio M, Gaita F, LeWinter M. Evaluation and treatment of pericarditis: a systematic review. JAMA. 2015;314(14):1498-506.

28. Ozaki Y, Tanaka A, Shimamoto K, Amuro H, Kawakami K, Son Y, et al. A case of rheumatoid pericarditis associated with a high IL-6 titer in the pericardial fluid and tocilizumab treatment. Mod Rheumatol. 2011;21(3):302-4.

29. Yoshida S, Takeuchi T, Sawaki H, Imai T, Makino S, Hanafusa T. Successful treatment with tocilizumab of pericarditis associated with rheumatoid arthritis. Mod Rheumatol. 2014;24(4):677-80.

30. Lebowitz WB. The heart in rheumatoid arthritis (rheumatoid disease). A clinical and pathological study of sixty-two cases. Ann Intern Med. 1963;58:102-23.

31. Guedes C, Bianchi-Fior P, Cormier B, Barthelemy B, Rat AC, Boissier MC. Cardiac manifestations of rheumatoid arthritis: a case-control transesophageal echocardiography study in 30 patients. Arthritis Rheum. 2001;45(2):129-35.

32. Hardouin P, Thevenon A, Beuscart R, Tison-Muchery F, Duquesnoy B, Thery C, et al. Evaluation of cardiac involvement in advanced rheumatoid arthritis. Clinical, electrocardiographic, echographic and gallium and thallium double scintigraphic study of 28 patients. Revue du rhumatisme et des maladies osteoarticulaires. 1988;55(9):683-7.

33. Steel KE, Kwong RY. Application of cardiac magnetic resonance imaging in cardiomyopathy. Curr Heart Fail Rep. 2008;5(3):128-35.

34. Slack JD, Waller B. Acute congestive heart failure due to the arteritis of rheumatoid arthritis: early diagnosis by endomyocardial biopsy. Angiology. 1986;37(6):477-82.

35. Joyce E, Fabre A, Mahon N. Hydroxychloroquine cardiotoxicity presenting as a rapidly evolving biventricular cardiomyopathy: key diagnostic features and literature review. Eur Heart J Acute Cardiovasc Care. 2013;2(1):77-83.

36. Nicola PJ, Maradit-Kremers H, Roger VL, Jacobsen SJ, Crowson CS, Ballman KV, et al. The risk of congestive heart failure in rheumatoid arthritis: 
a population-based study over 46 years. Arthritis Rheum. 2005;52(2):412-20.

37. Chung ES, Packer M, Lo KH, Fasanmade AA, Willerson JT, Anti TNFTACHFI. Randomized, double-blind, placebo-controlled, pilot trial of infliximab, a chimeric monoclonal antibody to tumor necrosis factor-alpha, in patients with moderate-to-severe heart failure: results of the anti-TNF therapy against congestive heart failure (ATTACH) trial. Circulation. 2003;107(25):3133-40.

38. Singh JA, Saag KG, Bridges SL Jr, Akl EA, Bannuru RR, Sullivan MC, et al. 2015 American College of Rheumatology Guideline for the treatment of rheumatoid arthritis. Arthritis Care Res. 2016;68(1):1-25.

39. Kumar N, Armstrong DJ. Cardiovascular disease-the silent killer in rheumatoid arthritis. Clin Med. 2008;8(4):384-7.

40. Roman MJ, Moeller E, Davis A, Paget SA, Crow MK, Lockshin MD, et al. Preclinical carotid atherosclerosis in patients with rheumatoid arthritis. Ann Intern Med. 2006;144(4):249-56.

41. Gonzalez-Juanatey C, Llorca J, Testa A, Revuelta J, Garcia-Porrua C, Gonzalez-Gay MA. Increased prevalence of severe subclinical atherosclerotic findings in long-term treated rheumatoid arthritis patients without clinically evident atherosclerotic disease. Medicine. 2003;82(6):407-13.

42. Ambrosino P, Lupoli R, Di Minno A, Tasso M, Peluso R, Di Minno MN. Subclinical atherosclerosis in patients with rheumatoid arthritis. A metaanalysis of literature studies. Thromb Haemost. 2015;113(5):916-30.

43. Wallberg-Jonsson S, Johansson H, Ohman ML, Rantapaa-Dahlqvist S. Extent of inflammation predicts cardiovascular disease and overall mortality in seropositive rheumatoid arthritis. A retrospective cohort study from disease onset. J Rheumatol. 1999;26(12):2562-71.

44. Lazzerini PE, Selvi E, Lorenzini S, Capecchi PL, Ghittoni R, Bisogno S, et al. Homocysteine enhances cytokine production in cultured synoviocytes from rheumatoid arthritis patients. Clin Exp Rheumatol. 2006;24(4):387-93.

45. Finley CE, LaMonte MJ, Waslien CI, Barlow CE, Blair SN, Nichaman MZ. Cardiorespiratory fitness, macronutrient intake, and the metabolic syndrome: the aerobics center longitudinal study. J Am Diet Assoc. 2006;106(5):673-9.

46. Peters MJ, Symmons DP, McCarey D, Dijkmans BA, Nicola P, Kvien TK, et al. EULAR evidence-based recommendations for cardiovascular risk management in patients with rheumatoid arthritis and other forms of inflammatory arthritis. Ann Rheum Dis. 2010;69(2):325-31.

47. Johnson AG, Nguyen TV, Day RO. Do nonsteroidal anti-inflammatory drugs affect blood pressure? A meta-analysis. Ann Intern Med. 1994;121(4):289-300.

48. Stamp LK, James MJ, Cleland LG. Diet and rheumatoid arthritis: a review of the literature. Semin Arthritis Rheum. 2005;35(2):77-94.
49. Choi HK, Hernan MA, Seeger JD, Robins JM, Wolfe F. Methotrexate and mortality in patients with rheumatoid arthritis: a prospective study. Lancet. 2002;359(9313):1173-7.

50. Dixon WG, Watson KD, Lunt M, Hyrich KL. British Society for Rheumatology biologics register control Centre C, Silman AJ, et al. reduction in the incidence of myocardial infarction in patients with rheumatoid arthritis who respond to anti-tumor necrosis factor alpha therapy: results from the British Society for Rheumatology biologics register. Arthritis Rheum. 2007;56(9):2905-12.

51. Voskuyl AE. The heart and cardiovascular manifestations in rheumatoid arthritis. Rheumatology. 2006;45(Suppl 4):iv4-7.

52. Ozgul M, Hoscan Y, Arslan C, Karabacak M. Complete atrioventricular block in a patient with rheumatoid arthritis. Turk Kardiyoloji Dernegi arsivi : Turk Kardiyoloji Derneginin yayin organidir. 2008;36(4):263-5.

53. Arakawa K, Yamazawa M, Morita Y, Kobayashi I, Horiguchi Y, Kamimura D, et al. Giant rheumatoid nodule causing simultaneous complete atrioventricular block and severe mitral regurgitation: a case report. J Cardiol. 2005;46(2):77-83.

54. Haque S, Bruce IN. Therapy insight: systemic lupus erythematosus as a risk factor for cardiovascular disease. Nat Clin Pract Cardiovasc Med. 2005;2(8):423-30.

55. Sidiropoulos PI, Karvounaris SA, Boumpas DT. Metabolic syndrome in rheumatic diseases: epidemiology, pathophysiology, and clinical implications. Arthritis Res Ther. 2008;10(3):207.

56. Miner JJ, Kim AH. Cardiac manifestations of systemic lupus erythematosus. Rheum Dis Clin N Am. 2014;40(1):51-60.

57. Doria A, Iaccarino L, Sarzi-Puttini P, Atzeni F, Turriel M, Petri M. Cardiac involvement in systemic lupus erythematosus. Lupus. 2005;14(9):683-6.

58. Cervera R, Font J, Pare C, Azqueta M, Perez-Villa F, Lopez-Soto A, et al. Cardiac disease in systemic lupus erythematosus: prospective study of 70 patients. Ann Rheum Dis. 1992;51(2):156-9.

59. Buppajamrntham T, Palavutitotai N, Katchamart W. Clinical manifestation, diagnosis, management, and treatment outcome of pericarditis in patients with systemic lupus erythematosus. Journal of the Medical Association of Thailand $=$ Chotmaihet thangphaet. 2014;97(12):1234-40.

60. Roman MJ, Salmon JE. Cardiovascular manifestations of rheumatologic diseases. Circulation. 2007;116(20):2346-55.

61. Rosenbaum E, Krebs E, Cohen M, Tiliakos A, Derk CT. The spectrum of clinical manifestations, outcome and treatment of pericardial tamponade in patients with systemic lupus erythematosus: a retrospective study and literature review. Lupus. 2009;18(7):608-12.

62. Weich HS, Burgess LJ, Reuter H, Brice EA, Doubell AF. Large pericardial effusions due to systemic 
lupus erythematosus: a report of eight cases. Lupus. 2005;14(6):450-7.

63. Pieretti J, Roman MJ, Devereux RB, Lockshin MD, Crow MK, Paget SA, et al. Systemic lupus erythematosus predicts increased left ventricular mass. Circulation. 2007;116(4):419-26.

64. Borenstein DG, Fye WB, Arnett FC, Stevens MB. The myocarditis of systemic lupus erythematosus: association with myositis. Ann Intern Med. 1978;89(5) Pt $1: 619-24$.

65. Micheloud D, Calderon M, Caparrros M, D'Cruz DP. Intravenous immunoglobulin therapy in severe lupus myocarditis: good outcome in three patients. Ann Rheum Dis. 2007;66(7):986-7.

66. Zawadowski GM, Klarich KW, Moder KG, Edwards WD, Cooper LT Jr. A contemporary case series of lupus myocarditis. Lupus. 2012;21(13):1378-84.

67. Law WG, Thong BY, Lian TY, Kong KO, Chng HH. Acute lupus myocarditis: clinical features and outcome of an oriental case series. Lupus. 2005;14(10):827-31.

68. Aggarwal P, Singh S, Suri D, Rawat A, Narula N, ManojKumar R. Rituximab in childhood lupus myocarditis. Rheumatol Int. 2012;32(6):1843-4.

69. Chan YK, Li EK, Tam LS, Chow LT, Ng HK. Intravenous cyclophosphamide improves cardiac dysfunction in lupus myocarditis. Scand J Rheumatol. 2003;32(5):306-8.

70. Appenzeller S, Pineau CA, Clarke AE. Acute lupus myocarditis: clinical features and outcome. Lupus. 2011;20(9):981-8.

71. Griveas I, Sourgounis A, Visvardis G, Zarifis I, Kyriklidou P, Sakellariou G. Immunoadsorption in lupus myocarditis. Therapeutic apheresis and dialysis. 2004;8(4):281-5.

72. Moroni G, La Marchesina U, Banfi G, Nador F, Vigano E, Marconi M, et al. Cardiologic abnormalities in patients with long-term lupus nephritis. Clin Nephrol. 1995;43(1):20-8.

73. Petri M. Thrombosis and systemic lupus erythematosus: the Hopkins lupus cohort perspective. Scand J Rheumatol. 1996;25(4):191-3.

74. Sultana Abdulaziz YA, Mohammed Samannodi and Mohammed Shabrawishi. Cardiovascular Involvement in Systemic Lupus Erythematosus, Systemic Lupus Erythematosus, Hani Almoallim InTech, https://doi.org/10.5772/37351. 2012.

75. Rahman P, Gladman DD, Urowitz MB, Yuen K, Hallett D, Bruce IN. The cholesterol lowering effect of antimalarial drugs is enhanced in patients with lupus taking corticosteroid drugs. J Rheumatol. 1999;26(2):325-30.

76. Bili A, Sartorius JA, Kirchner HL, Morris SJ, Ledwich LJ, Antohe JL, et al. Hydroxychloroquine use and decreased risk of diabetes in rheumatoid arthritis patients. J Clin Rheumatol. 2011;17(3):115-20.

77. Moyssakis I, Tektonidou MG, Vasilliou VA, Samarkos M, Votteas V, Moutsopoulos HM. Libman-sacks endocarditis in systemic lupus erythematosus: prevalence, associations, and evolution. Am J Med. 2007;120(7):636-42.

78. Hojnik M, George J, Ziporen L, Shoenfeld Y. Heart valve involvement (Libman-sacks endocarditis) in the antiphospholipid syndrome. Circulation. 1996;93(8):1579-87.

79. Roldan CA, Qualls CR, Sopko KS, Sibbitt WL Jr. Transthoracic versus transesophageal echocardiography for detection of Libman-sacks endocarditis: a randomized controlled study. J Rheumatol. 2008;35(2):224-9.

80. Asherson RA, Cervera R. Antiphospholipid antibodies and the heart. Lessons and pitfalls for the cardiologist. Circulation. 1991;84(2):920-3.

81. Morin AM, Boyer AS, Nataf P, Gandjbakhch I. Mitral insufficiency caused by systemic lupus erythematosus requiring valve replacement: three case reports and a review of the literature. Thorac Cardiovasc Surg. 1996;44(6):313-6.

82. Hoffman R, Lethen H, Zunker U, Schondube FA, Maurin N, Sieberth HG. Rapid appearance of severe mitral regurgitation under high-dosage corticosteroid therapy in a patient with systemic lupus erythematosus. Eur Heart J. 1994;15(1):138-9.

83. Janosik DL, Osborn TG, Moore TL, Shah DG, Kenney RG, Zuckner J. Heart disease in systemic sclerosis. Semin Arthritis Rheum. 1989;19(3):191-200.

84. Allanore Y, Meune C. Primary myocardial involvement in systemic sclerosis: evidence for a microvascular origin. Clin Exp Rheumatol. 2010;28(5 Suppl 62):S48-53.

85. Moyssakis I, Papadopoulos DP, Anastasiadis G, Vlachoyannopoulos P. Hypertrophic cardiomyopathy in systemic sclerosis. A report of two cases. Clin Rheumatol. 2006;25(3):404-6.

86. Tzelepis GE, Kelekis NL, Plastiras SC, Mitseas P, Economopoulos N, Kampolis C, et al. Pattern and distribution of myocardial fibrosis in systemic sclerosis: a delayed enhanced magnetic resonance imaging study. Arthritis Rheum. 2007;56(11):3827-36.

87. Lambova S. Cardiac manifestations in systemic sclerosis. World J Cardiol. 2014;6(9):993-1005.

88. Bulkley BH, Ridolfi RL, Salyer WR, Hutchins GM. Myocardial lesions of progressive systemic sclerosis. A cause of cardiac dysfunction. Circulation. 1976;53(3):483-90.

89. Vacca A, Siotto P, Cauli A, Montisci R, Garau P, Ibba $\mathrm{V}$, et al. Absence of epicardial coronary stenosis in patients with systemic sclerosis with severe impairment of coronary flow reserve. Ann Rheum Dis. 2006;65(2):274-5.

90. Akram MR, Handler CE, Williams M, Carulli MT, Andron M, Black CM, et al. Angiographically proven coronary artery disease in scleroderma. Rheumatology. 2006;45(11):1395-8.

91. de Groote P, Gressin V, Hachulla E, Carpentier P, Guillevin L, Kahan A, et al. Evaluation of cardiac abnormalities by Doppler echocardiography in a large nationwide multicentric cohort of 
patients with systemic sclerosis. Ann Rheum Dis. 2008;67(1):31-6.

92. Allanore Y, Avouac J, Kahan A. Systemic sclerosis: an update in 2008. Joint Bone Spine: revue du rhumatisme. 2008;75(6):650-5.

93. Vignaux O, Allanore Y, Meune C, Pascal O, Duboc D, Weber S, et al. Evaluation of the effect of nifedipine upon myocardial perfusion and contractility using cardiac magnetic resonance imaging and tissue Doppler echocardiography in systemic sclerosis. Ann Rheum Dis. 2005;64(9):1268-73.

94. Champion HC. The heart in scleroderma. Rheum Dis Clin N Am. 2008;34(1):181-90. viii

95. Steen V. The heart in systemic sclerosis. Curr Rheumatol Rep. 2004;6(2):137-40.

96. Kružliak P, Kováčová G, Balogh Š. Pericardial effusion as a first sign of systemic scleroderma. Cor Vasa. 54(4):e258-e60.

97. Kitchongcharoenying P, Foocharoen C, Mahakkanukrauh A, Suwannaroj S, Nanagara R. Pericardial fluid profiles of pericardial effusion in systemic sclerosis patients. Asian Pac J Allergy Immunol. 2013;31(4):314-9.

98. Amigo MC. The heart and APS. Clin Rev Allergy Immunol. 2007;32(2):178-83.

99. Erkan D, Harrison MJ, Levy R, Peterson M, Petri M, Sammaritano L, et al. Aspirin for primary thrombosis prevention in the antiphospholipid syndrome: a randomized, double-blind, placebo-controlled trial in asymptomatic antiphospholipid antibody-positive individuals. Arthritis Rheum. 2007;56(7):2382-91.

100. Cervera R. Antiphospholipid syndrome. Thromb Res. 2017;151(Suppl 1):S43-S7.

101. Ozkan Y. Cardiac involvement in Ankylosing spondylitis. J Clin Med Res. 2016;8(6):427-30.

102. Kazmierczak J, Peregud-Pogorzelska M, Biernawska J, Przepiera-Bedzak H, Goracy J, Brzosko I, et al. Cardiac arrhythmias and conduction disturbances in patients with ankylosing spondylitis. Angiology. 2007;58(6):751-6.

103. Ryall NH, Helliwell P. A Critical Review of Ankylosing Spondylitis. 1998;10(3):265-301.

104. Bulkley BH, Roberts WC. Ankylosing spondylitis and aortic regurgitation. Description of the characteristic cardiovascular lesion from study of eight necropsy patients. Circulation. 1973;48(5):1014-27.

105. Bergfeldt L. HLA-B27-associated cardiac disease. Ann Intern Med. 1997;127(8) Pt 1:621-9.

106. Moyssakis I, Gialafos E, Vassiliou VA, Boki K, Votteas V, Sfikakis PP, et al. Myocardial performance and aortic elasticity are impaired in patients with ankylosing spondylitis. Scand J Rheumatol. 2009;38(3):216-21.

107. Roldan CA, Chavez J, Wiest PW, Qualls CR, Crawford $\mathrm{MH}$. Aortic root disease and valve disease associated with ankylosing spondylitis. J Am Coll Cardiol. 1998;32(5):1397-404.

108. Crowley JJ, Donnelly SM, Tobin M, FitzGerald O, Bresnihan B, Maurer BJ, et al. Doppler echocardio- graphic evidence of left ventricular diastolic dysfunction in ankylosing spondylitis. Am J Cardiol. 1993;71(15):1337-40.

109. Brewerton DA, Gibson DG, Goddard DH, Jones TJ, Moore RB, Pease CT, et al. The myocardium in ankylosing spondylitis. A clinical, echocardiographic, and histopathological study. Lancet. 1987;1(8540):995-8.

110. Ribeiro P, Morley KD, Shapiro LM, Garnett RA, Hughes GR, Goodwin JF. Left ventricular function in patients with ankylosing spondylitis and Reiter's disease. Eur Heart J. 1984;5(5):419-22.

111. Lautermann D, Braun J. Ankylosing spondylitis-cardiac manifestations. Clin Exp Rheumatol. 2002;20(6 Suppl 28):S11-5.

112. Dik VK, Peters MJ, Dijkmans PA, Van der Weijden MA, De Vries MK, Dijkmans BA, et al. The relationship between disease-related characteristics and conduction disturbances in ankylosing spondylitis. Scand J Rheumatol. 2010;39(1):38-41.

113. Toussirot E, Bahjaoui-Bouhaddi M, Poncet JC, Cappelle S, Henriet MT, Wendling D, et al. Abnormal autonomic cardiovascular control in ankylosing spondylitis. Ann Rheum Dis. 1999;58(8):481-7.

114. Jamnitski A, Visman IM, Peters MJ, Boers M, Dijkmans BA, Nurmohamed MT. Prevalence of cardiovascular diseases in psoriatic arthritis resembles that of rheumatoid arthritis. Ann Rheum Dis. 2011;70(5):875-6.

115. Han C, Robinson DW Jr, Hackett MV, Paramore LC, Fraeman KH, Bala MV. Cardiovascular disease and risk factors in patients with rheumatoid arthritis, psoriatic arthritis, and ankylosing spondylitis. J Rheumatol. 2006;33(11):2167-72.

116. Chiu HY, Chang WL, Huang WF, Wen YW, Tsai YW, Tsai TF. Increased risk of arrhythmia in patients with psoriatic disease: a nationwide populationbased matched cohort study. J Am Acad Dermatol. 2015;73(3):429-38.

117. Khalid U, Ahlehoff O, Gislason GH, Kristensen SL, Skov L, Torp-Pedersen C, et al. Psoriasis and risk of heart failure: a nationwide cohort study. Eur J Heart Fail. 2014;16(7):743-8.

118. Abuabara K, Azfar RS, Shin DB, Neimann AL, Troxel AB, Gelfand JM. Cause-specific mortality in patients with severe psoriasis: a population-based cohort study in the UK. The British journal of dermatology. 2010;163(3):586-92.

119. Ahlehoff O, Gislason GH, Charlot M, Jorgensen $\mathrm{CH}$, Lindhardsen $\mathrm{J}$, Olesen $\mathrm{JB}$, et al. Psoriasis is associated with clinically significant cardiovascular risk: a Danish nationwide cohort study. J Intern Med. 2011;270(2):147-57.

120. Reich K. The concept of psoriasis as a systemic inflammation: implications for disease management. JEADV. 2012;26(Suppl 2):3-11.

121. Reaven GM. Banting lecture 1988. Role of insulin resistance in human disease. Diabetes. 1988;37(12):1595-607. 
122. Reilly MP, Rader DJ. The metabolic syndrome: more than the sum of its parts? Circulation. 2003;108(13):1546-51.

123. Cameron AJ, Boyko EJ, Sicree RA, Zimmet PZ, Soderberg S, Alberti KG, et al. Central obesity as a precursor to the metabolic syndrome in the AusDiab study and Mauritius. Obesity. 2008;16(12):2707-16.

124. Li ZY, Wang P, Miao CY. Adipokines in inflammation, insulin resistance and cardiovascular disease. Clin Exp Pharmacol Physiol. 2011;38(12):888-96.

125. McFarlane SI, Banerji M, Sowers JR. Insulin resistance and cardiovascular disease. J Clin Endocrinol Metab. 2001;86(2):713-8.

126. Dessein PH, Joffe BI. Insulin resistance and impaired beta cell function in rheumatoid arthritis. Arthritis Rheum. 2006;54(9):2765-75.

127. Dessein PH, Tobias M, Veller MG. Metabolic syndrome and subclinical atherosclerosis in rheumatoid arthritis. J Rheumatol. 2006;33(12):2425-32.

128. Chung CP, Oeser A, Solus JF, Avalos I, Gebretsadik T, Shintani A, et al. Prevalence of the metabolic syndrome is increased in rheumatoid arthritis and is associated with coronary atherosclerosis. Atherosclerosis. 2008;196(2):756-63.

129. Rostom S, Mengat M, Lahlou R, Hari A, Bahiri R, Hajjaj-Hassouni N. Metabolic syndrome in rheumatoid arthritis: case control study. BMC Musculoskelet Disord. 2013;14:147.

130. El Magadmi M, Ahmad Y, Turkie W, Yates AP, Sheikh N, Bernstein RM, et al. Hyperinsulinemia, insulin resistance, and circulating oxidized low density lipoprotein in women with systemic lupus erythematosus. J Rheumatol. 2006;33(1):50-6.

131. Demir S, Artim-Esen B, Sahinkaya Y, Pehlivan O, Alpay-Kanitez N, Omma A, et al. Metabolic syndrome is not only a risk factor for cardiovascular diseases in systemic lupus erythematosus but is also associated with cumulative organ damage: a cross-sectional analysis of 311 patients. Lupus. 2016;25(2):177-84.

132. Parker B, Urowitz MB, Gladman DD, Lunt M, Bae SC, Sanchez-Guerrero J, et al. Clinical associations of the metabolic syndrome in systemic lupus erythematosus: data from an international inception cohort. Ann Rheum Dis. 2013;72(8):1308-14.

133. Tso TK, Huang WN. Elevation of fasting insulin and its association with cardiovascular disease risk in women with systemic lupus erythematosus. Rheumatol Int. 2009;29(7):735-42.

134. Arida A, Protogerou AD, Konstantonis G, Konsta M, Delicha EM, Kitas GD, et al. Subclinical atherosclerosis is not accelerated in patients with Ankylosing spondylitis with low disease activity: new data and Metaanalysis of published studies. J Rheumatol. 2015;42(11):2098-105.

135. Neimann AL, Shin DB, Wang X, Margolis DJ, Troxel AB, Gelfand JM. Prevalence of cardiovascular risk factors in patients with psoriasis. J Am Acad Dermatol. 2006;55(5):829-35.
136. Ford ES, Giles WH, Dietz WH. Prevalence of the metabolic syndrome among US adults: findings from the third National Health and nutrition examination survey. JAMA. 2002;287(3):356-9.

137. Hu G, Qiao Q, Tuomilehto J, Balkau B, BorchJohnsen K, Pyorala K, et al. Prevalence of the metabolic syndrome and its relation to all-cause and cardiovascular mortality in nondiabetic European men and women. Arch Intern Med. 2004;164(10):1066-76.

138. Mebazaa A, El Asmi M, Zidi W, Zayani Y, Cheikh Rouhou R, El Ounifi S, et al. Metabolic syndrome in Tunisian psoriatic patients: prevalence and determinants. JEADV. 2011;25(6):705-9.

139. Qureshi AA, Choi HK, Setty AR, Curhan GC. Psoriasis and the risk of diabetes and hypertension: a prospective study of US female nurses. Arch Dermatol. 2009;145(4):379-82.

140. Boehncke S, Salgo R, Garbaraviciene J, Beschmann $\mathrm{H}$, Hardt K, Diehl S, et al. Effective continuous systemic therapy of severe plaque-type psoriasis is accompanied by amelioration of biomarkers of cardiovascular risk: results of a prospective longitudinal observational study. JEADV. 2011;25(10):1187-93.

141. Rathmann W, Funkhouser E, Dyer AR, Roseman JM. Relations of hyperuricemia with the various components of the insulin resistance syndrome in young black and white adults: the CARDIA study. Coronary artery risk development in young adults. Ann Epidemiol. 1998;8(4):250-61.

142. Facchini F, Chen YD, Hollenbeck CB, Reaven GM. Relationship between resistance to insulinmediated glucose uptake, urinary uric acid clearance, and plasma uric acid concentration. JAMA. 1991;266(21):3008-11.

143. Vazquez-Mellado J, Garcia CG, Vazquez SG, Medrano G, Ornelas M, Alcocer L, et al. Metabolic syndrome and ischemic heart disease in gout. J Clin Rheumatol. 2004;10(3):105-9.

144. Rho YH, Choi SJ, Lee YH, Ji JD, Choi KM, Baik $\mathrm{SH}$, et al. The prevalence of metabolic syndrome in patients with gout: a multicenter study. J Korean Med Sci. 2005;20(6):1029-33.

145. Choi HK, Ford ES, Li C, Curhan G. Prevalence of the metabolic syndrome in patients with gout: the third National Health and nutrition examination survey. Arthritis Rheum. 2007;57(1):109-15.

146. Pawlosky N. Cardiovascular risk: Are all NSAIDs alike? CPJ = RPC. 2013;146(2):80-3.

147. Nissen SE, Yeomans ND, Solomon DH, Luscher TF, Libby P, Husni ME, et al. Cardiovascular safety of Celecoxib, naproxen, or ibuprofen for arthritis. N Engl J Med. 2016;375(26):2519-29.

148. Avina-Zubieta JA, Abrahamowicz M, De Vera MA, Choi HK, Sayre EC, Rahman MM, et al. Immediate and past cumulative effects of oral glucocorticoids on the risk of acute myocardial infarction in rheumatoid arthritis: a population-based study. Rheumatology. 2013;52(1):68-75. 
149. Petramala L, Lorenzo D, Iannucci G, Concistre A, Zinnamosca L, Marinelli C, et al. Subclinical atherosclerosis in patients with Cushing syndrome: evaluation with carotid intima-media thickness and ankle-brachial index. Endocrinol Metab. 2015;30(4):488-93.

150. Seriolo B, Paolino S, Sulli A, Fasciolo D, Cutolo M. Effects of anti-TNF-alpha treatment on lipid profile in patients with active rheumatoid arthritis. Ann N Y Acad Sci. 2006;1069:414-9.

151. Robertson J, Peters MJ, McInnes IB, Sattar N. Changes in lipid levels with inflammation and therapy in RA: a maturing paradigm. Nat Rev Rheumatol. 2013;9(9):513-23.

152. Rao VU, Pavlov A, Klearman M, Musselman D, Giles JT, Bathon JM, et al. An evaluation of risk factors for major adverse cardiovascular events during tocilizumab therapy. Arthritis Rheumatols. 2015;67(2):372-80.

153. Charles-Schoeman C, Gonzalez-Gay MA, Kaplan I, Boy M, Geier J, Luo Z, et al. Effects of tofacitinib and other DMARDs on lipid profiles in rheumatoid arthritis: implications for the rheumatologist. Semin Arthritis Rheum. 2016;46(1):71-80.

154. Abella V, Scotece M, Conde J, Lopez V, Lazzaro $\mathrm{V}$, Pino J, et al. Adipokines, metabolic syndrome and rheumatic diseases. J Immunol Res. 2014;2014:343746.

155. Bhatia GS, Sosin MD, Patel JV, Grindulis KA, Khattak FH, Hughes EA, et al. Left ventricu- lar systolic dysfunction in rheumatoid disease: an unrecognized burden? J Am Coll Cardiol. 2006;47(6):1169-74.

156. Lee JL, Naguwa SM, Cheema GS, Gershwin ME. Revisiting Libman-sacks endocarditis: a historical review and update. Clin Rev Allergy Immunol. 2009;36(2-3):126-30.

157. Gramling A, O'Dell JR. Initial management of rheumatoid arthritis. Rheum Dis Clin N Am. 2012;38(2):311-25.

158. Wei L, MacDonald TM, Walker BR. Taking glucocorticoids by prescription is associated with subsequent cardiovascular disease. Ann Intern Med. 2004;141(10):764-70.

159. Stone NJ, Robinson JG, Lichtenstein AH, Bairey Merz CN, Blum CB, Eckel RH, et al. 2013 ACC/ AHA guideline on the treatment of blood cholesterol to reduce atherosclerotic cardiovascular risk in adults: a report of the American College of Cardiology/American Heart Association task force on practice guidelines. Circulation. 2014;129(25 Suppl 2):S1-45.

160. Rubin LJ, Badesch DB, Barst RJ, Galie N, Black $\mathrm{CM}, \mathrm{Keogh} \mathrm{A}$, et al. Bosentan therapy for pulmonary arterial hypertension. $\mathrm{N}$ Engl $\mathrm{J}$ Med. 2002;346(12):896-903.

161. Park K, Bavry AA. Aspirin: its risks, benefits, and optimal use in preventing cardiovascular events. Cleve Clin J Med. 2013;80(5):318-26.

Open Access This chapter is licensed under the terms of the Creative Commons Attribution 4.0 International License (http://creativecommons.org/licenses/by/4.0/), which permits use, sharing, adaptation, distribution and reproduction in any medium or format, as long as you give appropriate credit to the original author(s) and the source, provide a link to the Creative Commons license and indicate if changes were made.

The images or other third party material in this chapter are included in the chapter's Creative Commons license, unless indicated otherwise in a credit line to the material. If material is not included in the chapter's Creative Commons license and your intended use is not permitted by statutory regulation or exceeds the permitted use, you will need to obtain permission directly from the copyright holder. 